\title{
Kınalızâde Ali Efendi'nin (ö. 979/1572) Tabakātü’l-mesâil Adlı Risalesinin Tahkik ve Tahlili
}

\author{
Orhan Ençakar
}

Hanefî̀ mezhebinde herhangi fikhî bir meseleye dair hüküm vermeden önce başta mezhep imamları olmak üzere mezhep ulemasından aktarılan mesâile bakıp, bunların geçtiği eserlerin ve mesâili aktarılan ulemanın mezhep içindeki konumuna göre hüküm vermeye önem gösterilmiş ve bu tutum zamanla usûl-i iftâda bir kriter haline gelmiştir. Özellikle fetva ve kaza makamında bulunan Hanefîler tercih edilecek görüşü belirlemek üzere mezhep ulemasını, onlardan aktarılan mesâili ve bu mesâilin geçtiği kitapları bilgi ve kaynak değeri açısından "tabakātü’l-fukahâ", "tabakātü’l-mesâil” ve “tabakātü’l-kütüb” gibi taksimlere tâbi tutarak ulema, mesâil ve kitaplar arasında bir hiyerarşi belirlemişlerdir.

Bu makale Osmanlı ulemasından Kınalızâde Ali Efendỉnin (ö. 979/1572) Hanefî̀ mezhebinde aktarılan mesâilin hiyerarşisi hakkında sonraki literatürü belirleyen Tabakātü'l-mesâil ismiyle meşhur risalesinin tahkik ve tahlilini konu edinmektedir. Kınalızâde Ali Efendi Hanefî mezhebi mesâiline dair mesailüll-usûl/zâhirürr-rivâye, mesailün-nevâdir/gayru zâhirìr-rivâye ve fetâvâ başlıkları altında ortaya koyduğu üçlü tasnifte özellikle usul ve nevâdire getirdiği yeni tanımlar ve bunlara örnek olarak zikrettiği eserler ile bu kavramlara erken dönemdekinden daha geniş bir anlam yüklemiştir.

Anahtar Kelimeler: Hanefî mezhebi, tabakātü’l-mesâil, zâhirürr-rivâye, gayru zâhirìrrivâye, usul, nevâdir, fetâvâ.

\section{Giriş}

Hanefî mezhebinde mezhep imamlarından aktarılan mesâil ile bunların yer aldığ

* Dr., TDV İslam Araştırmaları Merkezi (İSAM), ORCID oooo-ooo1-6629-6965 orhan.encakar@isam.org.tr

Değerli dostlarım Said Kayacı, Okan Kadir Yılmaz ve Münzir Şeyhhasan’a, ayrıca derginin hakemlerine eleştiri ve katkıları için, Türkiye Yazma Eserler Kurumu ve İSAM’a da risalenin yazma nüshalarına erişimimde sağladıkları imkânlar için teşekkür ediyorum. 
981), Kudûrî (ö. 428/1037), Hüseyin b. Ali es-Saymerî (ö. 436/1045) ve Nâtıfî (ö. 446/1054) gibi Bağdat Hanefî fakihleri tarafından kaleme alınmış erken dönemin ${ }^{1}$ bazı kaynaklarında usul, câmiayn/cevâmi', emâlî ve nevâdir kavramlarıyla ifade edilmiştir. ${ }^{2}$ Daha sonraları bu mesâili ifade etmek üzere zâhirür-rivâye ve gayru zâhirir-rivâye üst kavramları geliştirilerek usul ile câmiayn/cevâmi' zâhirürr-rivâye üst kavramı; emâlî ile nevâdir ise gayru zâhirir-rivâye üst kavramı altında yer almaya başlamıştır.

Osmanlı ulemasından Kınalızâde Ali Efendi (ö. 979/1572) Hanefî mezhebi mesâil tasnifine dair yazdığı risalesinde bu ikili tasnife mezhebin diğer fakihlerinden fetâvâ ve vâkıât adıyla aktarılan mesâili de ekleyip mezhebin bütün fıkıh mesâilini üç başılık altında toplamıştır. Kınalızâde’nin Tabakātülmesâil adıyla meşhur olan bu risalesi konuya dair yazıldığı bilinen ilk ve tek müstakil risale olma özelliğine sahiptir. Risale kendisinden sonra konu hakkında bilgi veren bir kısmı aşağıda zikredilecek eserlerin de temel kaynağ olmuş ve geç dönemde mezhep mesâiline dair yapılan tasnif ve tanımlar onun bu risalesinde ortaya koyduğu tasnif ve tanımlara göre şekillenmiştir.

Elinizdeki makale Kınalızâde Ali Efendinin ilgili risalesinin tahlil ve tahkikini konu edinmekte olup makalenin birinci kısmında risalenin adı, müellife aidiyeti, telif tarihi ve sebebi, telif süreci, konusu, kaynakları, literatürdeki yeri, nüshaları hakkında bilgi verilmekte ve ilgili kavramlar açısından değerlendirmesi yapılmaktadır. İkinci kısmında ise risalenin üç ayrı versiyonunun tahkikli neşrine yer verilmiştir.

\section{I. İnceleme Kısmı}

\section{Risalenin Adı ve Müellife Aidiyeti}

Nüshalardaki farklı isimlendirmelerden hareketle Kınalızâde Ali Efendi’nin risalesine özel bir isim vermediğini söyleyebiliriz. Bu sebeple olsa gerek nüshalarda risalenin adının birkaç şekilde kaydedildiği görülmektedir. Tespit edebildiğim otuzdan fazla nüshadan beşinde risalenin adı Risâle fî̀ beyâni istılâhâti’l-mütedâvile fî kütübil-fikh, ${ }^{3}$ iki nüshada da Risâle fî beyâni

1 Bu makalede erken (mütekaddim) dönemle mezhebin ortaya çıkışından Kınalızâde Ali Efendi'nin risalesini yazdığı X. (XVI.) yüzyıla kadar geçen süre, geç (mütekaddim) dönemle de ilgili yüzylldan günümüze kadar geçen süre kastedilmektedir (bu dönemlendirme için bk. Ençakar, Hanefî Mezhebi Nevâdir Literatürü, s. 3-4).

2 Bu kavramların erken dönemde kullanılışına örnek olarak bk. Saymerî, Ahbâru Ebî Hanîfe, s. 161, 162, 163, 164, 168, 169, 170, 173; ayrıca bk. Ençakar, Hanefî Mezhebi Nevâdir Literatürü, s. 44-48, 52-54, 64-71.

3 Bu nüshalar şunlardır: Süleymaniye Ktp., Esad Efendi, nr. 3782; İzmir Millî Ktp., nr. 1866; Konya Bölge Yazma Eserler Ktp., nr. 3263; Manisa İl Halk Ktp., nr. 2226; İstanbul Üniversitesi Ktp., Nadir Eserler, nr. AY6405. 
mesâili ashâbil-Hanefiyye şeklindedir. ${ }^{4}$ Risalenin adının kayıtlı olduğu diğer bütün nüshalarda ise Tabakâtüll-mesâil adı yer almakta olup nüshaların çoğunda yer alması ve daha meşhur olması sebebiyle tahkikte "Tabakātüllmesâil" ismi tercih edilmiştir.

Risalenin müellife aidiyeti konusunda herhangi bir şüphe yoktur. Risale hemen bütün nüshalarında Kınalızâde Ali Efendi’ye nispet edildiği gibi kendisi risalenin benzer bir versiyonuna Molla Hüsrev'in (ö. 885/1480) Dürerü’lhükkâm isimli fıkıh eserine yazdığg haşiyesi içerisinde de yer vermiştir. ${ }^{5}$

\section{Telif Tarihi ve Sebebi}

Risalenin telif tarihi ve sebebine dair elimizde kesin bir veri bulunmamaktadır. Fakat risalede tasnif ve tanımı yapılan tabakātü'l-mesâil konusu Kınalızâde Ali Efendi öncesinde çeşitli fikıh kitaplarında zâhirür-rivâye ve gayru zâhirir-rivâye eserlerinin hangileri olduğu noktasında ele alınmış olup özellikle fetva ve yargı makamındaki müftülerin ve kadıların ilgi odağında yer alan bir mesele olagelmiştir.

Elimizdeki nüshalara göre Kınalızâde Ali Efendi’nin bu risalesinin ilk müstakil hali, iki kısımdan oluşmaktadır. Birinci kısma ait bir nüshanın başında Kınalızâde'nin bu bilgileri diğer bir Hanefî fakihi İbn Kutluboğa’nın (ö. 879/1474) kendi el yazısıyla yazdıklarından topladığ 1 ifade edilmektedir. ${ }^{6}$ İbn Kutluboğa’nın yazdıkları elimizde olmadığı için risalenin birinci kısmında yer alan bilgilerin ne kadarının ondan alındığını kesin olarak bilemiyoruz. Kınalızâde İbn Kutluboğảnın doğup yaşadığı Kahire'de bir süre (974/1566) kadılık yapmıştır. Buna göre İbn Kutluboğảnın tuttuğu notları Kahire'de kadılık yaptığı dönemde görmüş olabileceği varsayılırsa risaleyi bu tarihlerde yazmış olduğu tahmin edilebilir.

\section{Telif Süreci}

Risalenin, biri Dürerü̉l-hükkâm haşiyesi içinde, ${ }^{7}$ biri de müstakil olmak üzere iki farklı versiyonu bulunmaktadır. Hatta risalenin müstakil versiyonunun üç farklı aşamadan geçerek son halini aldığı anlaşılmaktadır. $\mathrm{Bu}$

4 Bu iki nüsha şunlardır: Süleymaniye Ktp., Hasan Hüsnü Paşa, nr. 509, 1192.

5 Bk. Kınalızâde, Hâşiye ale'l-Dürer, Süleymaniye Ktp., Şehid Ali Paşa, nr. 749, vr. 91 a -92 a Yenicami, nr. 397, vr. $70^{\mathrm{b}}-71^{\mathrm{a}}$; Kasîdecizâde Süleyman Sırrı, nr. 2454, nr. $72^{\mathrm{b}}-73^{\mathrm{a}}$.

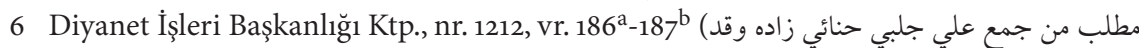
(جمعها من خط الشيخ قاسم بن قطلوبغا (ج)

7 Risalenin haşiye içinde yer alan versiyonundan beni haberdar eden kıymetli dostum Okan Kadir Yılmaz’a teșekkür ederim. 
müstakil versiyon önceleri iki ayrı parçadan oluşurken ${ }^{8}$ daha sonra bu iki parça kanaatimizce Kınalızâde Ali Efendi tarafından yeniden kompoze edilerek risalenin müstakil ikinci versiyonu, ardından da bazı takdim ve tehirlerle geliştirilerek müstakil üçüncü versiyonu üretilmiştir. Risalenin hem haşiye içindeki hem de müstakil üç versiyonuna ait nüshalar mevcut olup bunlar hakkında ayrıntılı bilgi aşağıda nüshaların tanıtıldığı bölümde verilmiştir.

\section{Konusu}

Risale, Hanefî mezhebi imamları ile mezhebin diğer fakihlerinden aktarılan görüşlerden oluşan bütün mezhep mesâilinin bilgi ve kaynak değeri açısından tasnifini ve tanımını ele almaktadır. Yukarıda ifade ettiğimiz üzere Hanefî mezhebinde özellikle mezhep imamlarından aktarılan mesâil zâhirür rivâye ve gayru zâhirir-rivâye olmak üzere ikiye ayrılmaktadır. Kınalızâde Ali Efendi bu taksime mezhebin diğer fakihlerinden fetâvâ ve vâkıât adıyla aktarılan görüşleri de ekleyerek bütün mezhep mesâilini üç türe ayırmış, her bir kısmı ifade etmekte kullanılan kavramları, bunların tanımlarını ve bu kısımlara giren önemli bazı eserlerin isimlerini zikretmiştir. ${ }^{9}$

Üç tür mesâile ait kavramlar ve tanımları risalenin son versiyonunda ele alındığg şekliyle şöyledir: ${ }^{10}$

1. Mesâilüll-usûl/zâhirür-rivâye: "Ulemâ-yı selâse" denilen mezhep imamları Ebû Hanîfe, Ebû Yûsuf ve Şeybânîden ayrıca "mütekaddimîn" adıyla bu üçüne eklenen Züfer ve Hasan b. Ziyâd gibi Ebû Hanîfe'nin talebelerinden rivayet edilen mesâile denir. Risalenin ilk müstakil versiyonunda, "Bununla birlikte zâhirür-rivâye denilince daha yaygın olarak sadece üç imamın görüşleri kastedilir" ifadesi yer almaktadır. Buna göre üç imamın dışındakilere ait görüşler mesâilü'l-usûl/zâhirürr-rivâyeden sayılmamaktadır.

8 Risalenin müstakil ilk versiyonuna ait nüshalardan birinde her iki parça da bulunmaktadır. Bu nüshayı bulmama vesile olan Taha Yasin Tan’a teșekkür ederim.

9 Kınalızâde'den çok daha önce Radıyyüddin es-Serahsî (ö. 571/1176) gibi yazdıkları kitaplarda fikıh mesâilini zâhiru'r-rivâye, gayru zâhirir-rivâye ve fetâvâ şeklinde toplayanlar olmuştur. Nitekim Kınalızâde de Radıyyüddin es-Serahsînin el-Muhît adlı eserini örnek vererek kitabın bu tertibini övmektedir. Bununla birlikte bu kitaplarda Hanefî mezhebi fikıh mesâilinin üç ayrı grupta toplandığı, her bir gruba ait mesâilin tanımının ne olduğu ve bu üç tür mesâilin hangi kitaplarda yer aldığı bu risaledeki kadar açık ifade edilmemiştir. Kınalızâde’nin risalesini değerli kılan tespit edebildiğim kadarıyla bu konuları ilk defa bu açıklıkta ve müstakil olarak ele almış olmasıdır.

10 Buradaki tanımlar risalenin son versiyonuna ait olduğunu düşündüğümüz nüshalara göre yapılmış ve diğer nüshalardaki tanım farkları belirtilmiştir. 
Bu mesâil Şeybânîye ait el-Mebsût,ez-Ziyâdât,el-Câmiu's-sagìr,el-Câmiu'lkebîr ve es-Siyer(ül-kebîr)'de ${ }^{11}$ yer alan meselelerden ibaret olup, güvenilir râviler aracıllğı 1 ile mütevâtir ya da meşhur yolla rivayet edilmiş olmaları sebebiyle bunlara zâhirürr-rivâye de denilir.

2. Mesâilün-nevâdir/gayru zâhirir-rivâye: Kınalızâde Ali Efendi nevâdir mesâilini: "Mezhep imamlarından, yukarıda adı geçen eserler dışında nakledilen meseleler” olarak tanımlar ve üç kısma ayırır.

a) Şeybânîye zâhirü'r-rivâye dışında nispet edilen eserlerde yer alan mesâil: el-Keysâniyyât, el-Hârûniyyât, el-Cürcâniyyât ve er-Rakkiyyât gibi eserler.

b) Talebelerinin Şeybânî̀den belli konularda aktardığı müstakil mesâil: Muhammed b. Semâa ve Muallâ b. Mansûr'un belli konularda Şeybânîden yaptıkları müstakil rivayetler gibi.

c) Ebû Hanîfe'nin Şeybânî dışındaki talebelerinin eserlerindeki mesâil: Hasan b. Ziyâd'ın el-Mücerred'i, Ebû Yûsuf'un el-Emâlîsi gibi eserler.

Kınalızâde Ali Efendi Dürer haşiyesinde mesâilün-nevâdir başlı̆̆1 altında zikredilen bütün şıklar için bunlara aynı zamanda gayru zâhirir-rivâye de denildiğini ifade ederken risalenin son versiyonunda a ve b şılarında yer alan eserlere -Şeybânîden, zâhirür-rivâye kitapları kadar nispeti sahih bir şekilde rivayet edilmedikleri gerekçesiyle- aynı zamanda gayru zâhirirrivâye denildiğini de aktarır. Onun bu ifadesinden sadece Şeybânîye ait eserleri zâhirürr-rivâye ve gayru zâhirirr-rivâye olarak gördüğü anlaşılmaktadır. Kınalızâde gayru zâhirir-rivâye eserlerine, "Ebû Hanîfe'nin Şeybânî dışındaki talebelerinin eserlerindeki mesâil” adı altında üçüncü bir kısmı daha ekleyerek Ebû Hanîfe'nin talebelerinin zâhirürr-rivâye dışında kalan bütün mesâilini ifade etmek üzere nevâdir kavramını öne çıkardığı görülmektedir.

3. Fetâvâ/vâkıât: Hakkında mezhep imamlarından (ashâbü'l-mezheb, elmütekaddimîn) rivayet aktarılmayan meselelere dair gelen sorulara cevap olarak mezhebin müteahhir alimlerinin (el-müctehidîn, el-müteahhirîn) kendi içtihatlarıyla ortaya koydukları mesâil.

11 Kınalızâde risalenin Dürer haşiyesi içindeki versiyonunda bu eserlere es-Siyerüs-sagì $r$ ' i de ekleyerek zâhirürr-rivâye eserlerini altı tane olarak saymıştır (bk. Kınalızâde, Hâş̧iye ale’l-Dürer, Süleymaniye Ktp., Şehid Ali Paşa, nr. 749, vr. 91 ${ }^{\mathrm{a}}$ ). 


\section{Kaynakları}

Yukarıda geçtiği üzere risalenin iki kısımdan oluşan müstakil ilk versiyonuna ait nüshalardan birinci kısmı içeren bir nüshada ${ }^{12}$ Kınalızâde Ali Efendi’nin birinci kısımdaki bilgileri İbn Kutluboğa’nın yazdıklarından aldığı ifade edilmektedir. Aynı nüshada zâhirürr-rivâye hakkında İbn Kutluboğa'dan yapılan nakiller kendisinin bu konuda bazı açıklamaları olduğunu göstermektedir. ${ }^{13}$ Kınalızâde’nin bir ara (974/1566) Kahire kadılığı da yapmış olduğu ve bu açıklamaların Kahire'de kendisinden ders alan Tenvîrü'l-ebsâr müellifi meşhur Hanefî fakihi Muhammed b. Abdullah et-Timurtaşînin (ö. 1006/1598) el-Fetâvâ’sının da bulunduğu bir mecmua içinde yer aldığ1 göz önünde bulundurulduğunda bunun talebesi Timurtaşî tarafından dile getirilmiş doğru bir iddia olma ihtimali artmaktadır.

Bununla birlikte İbn Kutluboğa'dan önce zâhirürr-rivâye ve gayru zâhiri'rrivâye hakkında tanımlama yapanlar arasında İtkānî (ö. 758/1357), ${ }^{14}$ Bâbertî (ö. 786/1384), ${ }^{15}$ Seyyid Şerîf el-Cürcânî (ö. 816/1413), ${ }^{16}$ Bedreddin el-Aynî (ö. 855/1451) ${ }^{17}$ ve Taşköprizâde (ö. 968/1561) ${ }^{18}$ gibi el-Hidâye üzerine şerh yazmış, Mısır'da tahsil, tedris veya kaza faaliyetlerinde bulunmuş, birbirinin akranı veya talebesi olmak gibi çeşitli ortak vasıflara sahip alimlerin bulunduğu görülür. ${ }^{19}$ Nitekim İtkānî ve Bâbertînin zâhirürr-rivâye ve gayru zâhirir-rivâye hakkındaki el-Hidâye şerhinde yaptıkları açıklamaları risalenin bazı nüshalarında kenar notu olarak geçmektedir.

12 Diyanet İşleri Başkanlığı Ktp., nr. 1212, vr. 186a

13 Diyanet İşleri Başkanlığı Ktp., nr. 1212, vr. 187º . Zâhirürr-rivâye hakkında İbn Kutluboğa'dan yapılan nakle risalenin ilk müstakil versiyonuna ait tahkikli metnin sonunda "fevâid" başlığı altında yer verilmiştir.

14 İtkānî, Gāyetü’l-beyân, vr. 30º . Emîr Kâtib’in nisbesi daha yaygın olarak İtkānî şeklinde okunur. Diğer taraftan kendisinden altı sene sonra vefat eden Safedî ile (ö. 764/1363) İbn Tağrîberdî (ö. 874/1470) bu kelimenin Etkān şeklinde fetha ile okunduğunu ifade eder (bk. A'yânü'l-asr, I, 622; el-Menhelü's-sâfî̀, III, 103). Leknevî (ö. 1304/1886) kelimenin kesre ile okunduğunu söyledikten sonra Çivizâde’nin bazı talebelerinden nakille Çivizâde'nin İtkānînin kendi hattıyla yazdı̆̆ı bir notta nisbesini Etkānî diye zaptettiğini aktarır (el-Fevâidül-behiyye, s. 50). Bununla birlikte İtkānînnin el-Müntehab üzerine yazdığ $e t$-Tebyîn isimli şerhin müellif hatlı bir nüshasının sonunda (Kütahya Vahîd Paşa Ktp., nr. 186, vr. 142 ${ }^{\mathrm{a}}$ ) kelime iki yerde kesre ile İtkānî olarak zaptedilmiştir.

15 Bâbertî, el-İnâye, I, 136; VIII, 371.

16 Cürcânî, et-Tarîfât, s. 32, 146.

17 Aynî, el-Binâye, I, 553.

18 Taşköprizâde, Miftâhu's-saâde, s. 638.

19 Bk. Ençakar, Hanefî Mezhebi Nevâdir Literatürü, s. 48-49. 
Buna göre Kınalızâde Ali Efendi’nin bu bilgileri birçok ortak vasfa sahip olup eserleri Osmanlı uleması tarafından ilgiliyle okunan bu kişi veya kişilerin eserlerinden istifadeyle bir araya getirmiş olması da mümkündür.

\section{Literatürdeki Yeri}

Kınalızâde Ali Efendỉnin kendisinden önceki ulemadan istifadeyle bu risalede ortaya koyduğu taksim ve tanımlar Hanefî fakihleri arasında kabul görerek hızla yayılmış ve sonrasında yazılan birçok önemli eserde aktarılagelmiştir. Günümüz modern çalışmalarında konuyla ilgili yapılan açılklamalar da bu risalede ortaya konulan taksim ve tanımlar etrafında şekillenmiştir. ${ }^{20}$

Kınalızâde Ali Efendi’nin bu risalesinin tamamını veya mesâilin üç türünü tanımladığı baş tarafını eserlerinde nesir veya manzum olarak doğrudan veya dolayll, bazan isim verip bazan da vermeden aktaran meşhur Hanefî uleması arasında Mahmûd b. Süleyman el-Kefevî (ö. 990/1582), ${ }^{21}$ Takıyyüddin b. Abdülkādir et-Temîmî (ö. 1010/1601), ${ }^{22}$ İsmâil b. Abdülganî en-Nablusî (ö. 1062/1652), ${ }^{23}$ Ahmed b. Muhammed el-Hamevî (ö. 1098/1687), ${ }^{24}$ Pîrîzâde İbrâhim (ö. 1099/1688), ${ }^{25}$ İbn Âbidîn Muhammed Emîn b. Ömer edDımaşkī (ö. 1252/1836), ${ }^{26}$ Muhammed Abdülhay b. Muhammed el-Leknevî (ö. 1304/1886) ${ }^{27}$ ve Ebü'l-Hasan Hârûn b. Bahâeddin el-Mercânî (ö. 1306/ $1888)^{28}$ gibi isimler bulunmaktadır. ${ }^{29}$

\section{7. Üzerine Yapılan Çalışmalar}

Elinizdeki tahkik çalışmasının hakemlik süreci devam ederken Kınalızâde Ali Efendỉnin bu risalesi, Temîmînin et-Tabakātüs-seniyye isimli eseri içinde aktardığı versiyonu esas alınarak yayımlandı..$^{30}$ Muhakkik risalenin tahkikinde Princeton Üniversitesi Kütüphanesi’nde kayıtlı (nr. 225Y) nüshası ile Süleymaniye Kütüphanesinnde kayıtlı (Esad Efendi, nr. 3652) nüshasından

20 Bk. Ençakar, Hanefî̀ Mezhebi Nevâdir Literatürü, s. 52.

21 Kefevî, Ketâib, I, 404-406.

22 Temîmî, et-Tabakātü's-seniyye, I, 42-46.

23 Nâblusî, el-İhkâm, vr. $26^{\mathrm{b}}-27^{\mathrm{a}}$.

24 Hamevî, İthâfül-ahbâb, vr. $148^{\mathrm{a}}$.

25 Pîrîzâde, Umdetü zevi'l-basâir, vr. $2^{\mathrm{a}}-3^{\mathrm{a}}$.

26 İbn Âbidîn, Şerhu Ukūdi resmi'l-müftî, I, 10-12.

27 Leknevî, en-Nâfiu'l-kebîr, s. 17-18; a.mlf., Umdetürr-riâye I, 40-43.

28 Mercânî, Nâzûratül-hak, s. 167-176. Ancak Mercânî zâhirür-rivâye eserlerini altı olarak saymıştır.

29 Bk. Ençakar, Hanefî Mezhebi Nevâdir Literatürü, s. 50-51.

3o Bk. Orazov, "Hanefi Fıkıh Edebiyatının Tasnifi", s. 365-96. 
da faydalandığını belirtmiștir. ${ }^{31}$ Muhakkikin tahkikte esas aldığı risalenin etTabakätüs-seniyye içindeki versiyonu ile Princeton nüshası risalenin birinci versiyonuna aittir. et-Tabakätüss-seniyye içindeki versiyonun müellif hattından alınmış olması, Princeton nüshasının başında da nüshanın Kınalızâde’nin talebelerinden birine dayandığını gösteren bir ifadenin bulunması muhakkikin tahkik için bu versiyonu seçmesinde etkili olmuş görünmektedir. Muhakkikin iyi bir nüsha araştırması yapmadan risaleyi tahkik ettiği ve risaleye ait farklı versiyonlardan haberdar olamadığı anlaşılmaktadır. Nitekim ikinci versiyona ait Esad Efendi nüshasındaki ilaveler için "diğer nüshalarda yer almayan" ifadesini kullanması ve bu ilaveleri dipnota koymass ${ }^{32}$ risalenin diğer versiyonlarının farkına varamadığını göstermektedir. Oysaki risalenin ikinci ve üçüncü versiyonuna ait yirmiden fazla nüsha bulunmaktadır. Diğer taraftan risalenin adı nüshaların çoğunda Tabakātül-mesâil olarak geçerken muhakkik yukarıda geçtiği üzere birkaç nüshada geçen Risâle fî beyâni ıstılâhâti'l-mütedâvile fî kütübil-fikh ismini tercih etmiştir. Hasılı muhakkikin bu neşri risalenin müstakil birinci versiyonuna ait bir neşir olup risalenin son halini yansıtmamaktadır. Elinizdeki bu neşirde ise risalenin Dürer haşiyesi içindeki versiyonu, iki bölümden oluşan müstakil birinci versiyonu ve bu iki bölümün birleştirilmesinden oluşan müstakil son versiyonu olmak üzere toplam üç versiyonun tahkiki yer almaktadır.

\section{Nüshaları}

Yukarıda geçtiği üzere risalenin nüshalarını incelediğimizde Kınalızâde Ali Efendỉnin tabakātü'l-mesâil hakkında yazdıklarının; biri Dürer haşiyesi içinde, diğer üçü de müstakil olmak üzere dört farklı versiyonunun bulunduğu ve bunların son iki versiyon hariç tek metinde cemedilemeyecek kadar birbirlerinden farklı oldukları görülmektedir. $\mathrm{Bu}$ sebeple risalenin biri haşiye içinde, ikisi de müstakil olmak üzere üç versiyonunun, hem cemedilmesi mümkün olmadığından hem de gelişimi görme açısından, ayrı olarak yayımlamak gerekmektedir. Risalenin farklı versiyonlarına ait nüshalardan ulaşabildiğimiz ve tahkikte kullandıklarımızın bilgileri şöyledir:

\subsection{Risalenin Dürer Haşiyesindeki Versiyonunu İçeren Nüshalar,

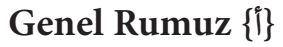

Risalenin bu versiyonu müstakil olmayıp Kınalızâde Ali Efendi’ye ait Dürer haşiyesi içinde Molla Hüsrev’in, "Bunun hükmünü zâhirürr-rivâyede

31 Bk. Orazov, “Hanefi Fıkıh Edebiyatının Tasnifi”, s. 381. 32 Bk. Orazov, “Hanefi Fıkıh Edebiyatının Tasnifi”, s. 381. 
zikretmedi” ifadesine yaptığı açıklamadan oluşmaktadır. Bu kısım, haşiyeden alındığı ifade edilerek, aşağıda gelecek ilk nüshada müstakil olarak da istinsah edilmiştir. Risalenin Dürer haşiyesindeki bu versiyonunun tahkikte kullanılan nüshaları șunlardır:

8.1.1. Diyanet İşleri Başkanlığı Kütüphanesi, nr. 2868 (vr. 552 $-552^{\mathrm{b}}$ ), Rumuz “د"

Kınalızâde Ali Efendi’nin Dürer hâşiyesinin ilgili bölümünün ayrı olarak istinsah edildiğini tespit edebildiğimiz tek nüshadır. Sonunda haşiyeden alındığ 1 kaydı vardır. Aynı hatla yazılmış bir önceki ve bir sonraki risalelerin sonunda yer alan bilgiye göre nüsha 10 Cemâziyelevvel 1270’te (8 Şubat 1854) (Kayseri) Ağırnaslı Mesud tarafından yazılmıştır.

8.1.2. Süleymaniye Kütüphanesi, Şehid Ali Paşa, nr. 749 (vr. 91 ${ }^{\mathrm{a}}-92^{\mathrm{a}}$ ), Rumuz “"

Nüsha kenarında mukabele kayıtları bulunmaktadır. Nüshanın ferağ kaydı yoktur. Tabakātü’l-mesâille alakalı haşiyenin başladığı yerde nüsha kenarına "matlab mühim" yazılmıştır.

8.1.3. Süleymaniye Kütüphanesi, Yenicami, nr. 397 (vr. $60^{\mathrm{b}}-61^{\mathrm{a}}$ ), Rumuz “ي”

Kınalızâde Ali Efendi, oğlu Hasan Çelebi ve Karamanîzâde’nin Dürer haşiyelerinin yer aldığı bu nüshanın da ferağ kaydı yoktur. Tabakātü’l-mesâille alakalı haşiyenin başladığı yerde nüsha kenarına kırmızı mürekkeple "matlab" yazılmıştır.

8.1.4. Süleymaniye Kütüphanesi, Kasîdecizâde Süleyman Sırrı, nr. 2454 (vr. 72b-73 $)$, Rumuz “ق”"

Nüshanın ferağ kaydı yoktur. Tabakātü’l-mesâille alakalı haşiyenin başladığ

8.1.5. Beyazıt Devlet Kütüphanesi, Veliyyüddin Efendi, nr. 1107 (vr. 97 (98 $\left.^{\mathrm{a}}\right)$, Rumuz “و”

Nüshanın ferağ kaydı yoktur. Tabakātü’l-mesâille alakalı haşiyenin başladığ1 yerde nüsha kenarına konunun önemli olduğunu ifade etmek üzere, "Matlab fì beyâni kütübi zâhirir-rivâye ve gayri zâhirir-rivâye ve ashâbihâ ve hüve mebhasun azîmün, feteemmelhu" yazılmıştır. ${ }^{33}$

\subsection{Risalenin Müstakil İlk Versiyonunu İçeren Nüshalar, Genel Rumuz $\{\varphi\}$}

Risalenin müstakil ilk versiyonunun iki ayrı kısımdan oluştuğu anlaşllmaktadır. Risalenin bu halini içeren tespit edebildiğimiz on beş nüsha

33 Bu başlık risalenin Dürer haşiyesi içindeki müstakil olmayan bu versiyonuna ait tahkikli metnin başına köşeli parantez içinde eklenmiştir. 
bulunmaktadır. Bu nüshalardan birinde her iki kısım ayrı olarak, diğerlerinde ise sadece birinci kısım bulunmaktadır. Bu nüshalardan aşağıdaki ilk altısı mukabelede kullanılmış, diğerleri ise içerdikleri hata ve eksikliklerden dolayı mukabeleye alınmamıştır.

8.2.1. Diyanet İşleri Başkanlığı Kütüphanesi, nr. 1212 (vr. $\left.186^{\mathrm{a}}-187^{\mathrm{b}}\right)$, Rumuz “ت”

Kahire kadısı olduğu dönemde Kınalızâde Ali Efendi'den ders okuyan Tenvîrüll-ebsâr müellifi Muhammed b. Abdullah et-Timurtaşînnin (ö. 1006/ 1598) el-Fetâvầsının da bulunduğu bir mecmua içinde yer alan risalenin bu nüshasının başında Kınalızâde’nin bu bilgileri İbn Kutluboğa’nın notlarından topladığını ifade eden kırmızı mürekkeple yazılmış bir matlap/başlık vardır. ${ }^{34}$

Risalenin müstakil ilk versiyonuna ait olduğunu düşündüğümüz bu kısmın hemen sonrasında biri İbn Kutluboğa’nın el yazısından, diğeri de İtkānî̉nin (ö. 758/1357) Gāyetü̉l-beyân isimli el-Hidâye şerhinden aktarılmış zâahirürr-rivâye ve gayru zâhirir-rivaye hakkında iki matlap (187 b) bulunmaktadir. $^{35}$

Nüshanın $189^{\mathrm{b}}$ ile $190^{\mathrm{a}}$ varaklarında Kınalızâde Ali Efendi’den aktarıldı̆̆ 1 ifade edilen bir başka matlap daha bulunmaktadır. Burada meşayihin içtihat, tahriç ve tercih faaliyetleriyle Şeybânînin (ö. 189/805) kitapları nasıl telif ettiğine dair açıklamalar bulunmaktadır. Risalenin ikinci kısmını oluşturan bu matlapta yer alan bilgiler, risalenin müstakil ilk versiyonunu içeren aşağıdaki diğer nüshaların hiçbirinde bulunmasa da risalenin müstakil ikinci ve üçüncü versiyonunu içeren diğer bütün nüshalarda mevcuttur.

Ferağ kaydı olmayan bu nüshanın başında temellük kaydı olduğu tahmin edilen silinmiş bir yazının altına tarih olarak 1089 (1678-9) yılı yazılmıştır. $\mathrm{Bu}$ nüshada tahkikte kullanılan diğer nüshalara nispetle daha fazla eksik ve hatalı kelime bulunduğu için önemli olanları dışında bu farklara dipnotlarda işaret edilmemiştir.

\subsubsection{Tokat İl Halk Kütüphanesi, nr. $123\left(v r .3^{\mathrm{b}}-4^{\mathrm{a}}\right)$, Rumuz “b”}

Mecmua içinde yer alan risalelerden birinin istinsah tarihi Safer ayının sonu 1082'dir (Nisan 1611). Risalenin adı nüshada Hâzihî risâletün fî beyâni tabakātil-mesâili li-Ali Çelebi el-marûf bi-Kınalizâde şeklinde kayıtlıdır.

34 Bu başlık, risalenin müstakil ilk versiyonuna ait tahkikli metnin başına kuşaklı parantez içinde eklenmiştir.

35 Konuyla alakalı olması sebebiyle bu iki matlap da risalenin ilk versiyonuna ait tahkikli metnin sonuna ayrı bir başlıkla eklenmiştir. 
Hatası az ve nispeten daha erken bir tarihe ait olan bu nüsha mukabelede kullanılmıştır.

8.2.3. Süleymaniye Kütüphanesi, Yahyâ Tevfik, nr. 439 (vr. $\left.75^{\mathrm{b}}-76^{\mathrm{a}}\right)$, Rumuz "ف"

Risale 01 Rebîülâhir 1037 (10 Aralık 1627) tarihinde Mustafa b. Ahmed et-Tûsî isimli kişi tarafından yazılmıștır. Nüshada risalenin adı yoktur. Bir önceki gibi hatası az ve nispeten erken bir tarihe ait olan bu nüsha da mukabelede kullanılmıştır.

8.2.4. Süleymaniye Kütüphanesi, Mihrişah Sultan, nr. 98 (vr. $217^{\text {b }}$ $218^{\text {b) }}$, Rumuz “p”

İbn Nüceym'in (ö. 970/1563) el-Eşbâh ve’n-nazâir isimli kitabına ait bir nüshasının sonunda yer alan risalenin müstensihi iki varak geride aynı hatla yazılmış el-Eşbâh'in ferağ kaydına göre Hasan b. Hâc el-Bosnevî olup Rebîulâhir sonu 1108 (25 Kasım 1696) tarihinde yazılmıştır. Varakları kırmızı cetvellidir. Risalenin kenarında İtkānî, Bâbertî ve Kemalpaşazâde’den nakledilmiş zâhirür r-rivâye ve usul hakkındaki açılamalar ve Kınalızâde’ye ait bir minhüvât kaydı yer almaktadır. ${ }^{36}$ Adı Risâle fì beyâni tabakāti’l-mesâil lìl-mevlâ el-merhûm Ali Efendi eş-şehîr bi-Kınalızâde olarak kayıtlıdır.

\subsubsection{Süleymaniye Kütüphanesi, Nuruosmaniye, nr. 2062 (vr. $\left.07^{\mathrm{b}}-08^{\mathrm{a}}\right)$ Rumuz “ن”}

Risalenin sonundaki kayda göre aşağıda gelecek Hâlet Efendi nüshası gibi Temîmînin (ö. 1010/1601) et-Tabakâtüs-seniyye isimli eserinden istinsah edilmiştir. Mecmuanın istinsah tarihi 1117'dir (1705-06). Risalenin başında risalenin adı verilmeden "lil-mevlâ el-allâme Ali Çelebi b. Emrullah eş-şehîr biKınalızâde rahimehullah" denilmekle yetinilmiştir. Risalenin kenarında ve sonunda yukarıda geçen Mihrişah Sultan nüshasında bulunan açıklamalar, müellife ait minhüvât kaydı ve bu açılamalarla ilgili bir yorum da bulunmaktadır. ${ }^{37}$

8.2.6. Süleymaniye Kütüphanesi, Hâlet Efendi, nr. 823 (vr. $76^{\mathrm{a}}-77^{\mathrm{a}}$ ), Rumuz “خ”

Risale bir önceki Nuruosmaniye nüshası gibi Temîmînin et-Tabakātüsseniyye isimli eserinden istinsah edilmiştir. Mecmuanın sonunda Hâlis Tosyevî adında bir müstensihin düştüğü 16 Şâban 1232 (Temmuz 1817)

$36 \mathrm{Bu}$ açıklamalara ve minhüvât kaydına risalenin son versiyonuna ait tahkikli metnin dipnotlarında yer verilmiştir.

37 Bu açıklama, minhüvât kaydı ve yorumlardan nüsha kenarında olanlara risalenin son versiyonuna ait tahkikli metnin dipnotunda, nüshanın sonunda yer alanlara ise tahkikli metnin sonunda yer verilmiştir. 
tarihli istinsah kaydı vardır. Bir önceki nüshada olduğu gibi bunda da risalenin adıverilemeden sadece "Risâle lil-mevlâ el-allâme Kınalızâde" denilmekle yetinilmiştir.

\subsubsection{Süleymaniye Kütüphanesi, Âtıf Efendi, nr. 2825 (vr. $26^{\mathrm{a}}-27^{\mathrm{a}}$ )}

Bir mecmua içinde bulunan risalenin bu versiyonu Recep 1077 (Aralık 1666) tarihinde Mahmûd b. Hasan b. Nezîr b. Mustafa b. İskender tarafından yazılmıştır. Risalenin adı nüshada "Hâzihî risâletün şerîfetün fî tabakätìlmesâili lìl-mevlâ el-merhûm Ali Çelebi el-Hinnâî rahimehullahu teâlâ" şeklinde kayitlıdır. Risalenin sonunda risalede dile getirilenlerin el-Hidâye ve benzeri Hanefî fıkıh kitaplarını mütalaasında lazım olan önemli bilgilerden olduğuna dair bir kayıt vardır. Bu kayıt aşağıda gelecek olan Çorum Hasan Paşa İl Halk (nr. 1512), Kastamonu İl Halk (nr. 3374), Princeton Üniversitesi (nr. 225Y) ve Beyazıt Devlet (Veliyyüddin Efendi, nr. 3236) kütüphanelerindeki nüshaların sonunda da yer almaktadır. ${ }^{38}$ Benzer hatalar barındıran bu beş nüsha mukabelede kullanılmamıştır.

\subsection{8. Çorum Hasan Paşa İl Halk Kütüphanesi, nr. 1512 (vr. $1^{\mathrm{b}}-3^{\mathrm{a}}$ )}

Risalenin ferağ kaydı yoktur. Ancak mecmua içinde aynı hatla yazılmış diğer iki risalenin sonunda yer alan bilgiye göre nüsha 1088'de (1677) Belgradcık kasabasında kadı iken Osman b. Şa ‘bân tarafından yazılmıştır. Risalenin adı bir önceki ve bir sonraki nüshada olduğu gibi "Hâzihî risâletün şerîfetün fî̀ tabakātill-mesâili li’l-mevlâ el-merhûm Ali Çelebi el-Hinnâî rahimehullahu teâlâ" şeklinde kayıtlıdır.

\subsubsection{Kastamonu İl Halk Kütüphanesi, nr. 3374 (vr. 209ª)}

Risalenin ferağ kaydı yoktur. Risalenin adı önceki iki nüshada olduğu gibi "Hâzihî risâletün şerîfetün fî tabakäti'l-mesâili lìl-mevlâ el-merhûm Ali Çelebi el-Hinnâî rahimehullahu teâlâ" şeklinde kayıtlıdır.

\subsubsection{Princeton Üniversitesi Kütüphanesi, nr. $225 Y$ (vr. $64^{\mathrm{b}}-65^{\mathrm{a}}$ )}

Bir mecmua içinde yer alan bu risalenin ferağ kaydı yoktur. Risalenin başında "Risâle li-efdalill-müteahhirîn üstâzî ve üstâzül-mütebahhirîn Ali Çelebi Efendi Hayâlîzâde (Hinnâizâde) Rahimehullah", sonunda ise benzer şekilde "Hâzâ lil-üstâd el-âlim el-mütebahhir, ferîdü dehrihî ve vahîdü asrihî Ali Çelebi Efendi Hayâlîzâde (Hinnâizâde) Rahimehullah" ifadesi yer almaktadır. Bu ifadelerden risalenin bu nüshada yer alan versiyonunun Kınalızâde’nin öğrencilerinden birine ait bir nüshaya dayandığı sonucu çıkarılabilir. Risalenin bu nüsha içindeki versiyonu çok hatalı olduğu için mukabelede kullanılmamıştır.

38 İlgili kayıt risalenin müstakil ilk versiyonuna ait tahkikli metnin dipnotuna eklenmiştir. 


\subsubsection{Beyazıt Devlet Kütüphanesi, Veliyyüddin Efendi, nr. 3236 (vr. 132 $-133^{\mathrm{a}}$ )}

Risalenin ferağ kaydı yoktur. Risalenin sonunda yukarıda geçen dört nüshada yer alan "risalede dile getirilenlerin el-Hidâye ve benzeri Hanefî fikıh kitaplarını mütalaasında lazım olan önemli bilgilerden olduğunu" ifade eden kayıt vardır.

\subsubsection{Süleymaniye Kütüphanesi, Esad Efendi, nr. 3782 (vr. $49^{\mathrm{b}}-50^{\mathrm{a}}$ )}

17 Zilkade 998 (17 Aralık 1590) gecesi istinsah edilen bu nüshadaki versiyonunun adı diğerlerinden farklı olarak, "Risâle fî beyâni ıstılâhâti'lmütedâvile fî kütübil-fikh mimmâ ellefehû el-merhûm Ali Çelebi eş-şehîr biHinnâizâde rahimehullahu rahmeten vâsiaten" şeklinde kayıtlıdır. İstinsah tarihi diğerlerine göre daha eski olmasına rağmen risalenin bu versiyonunu içeren nüshada çok fazla eksik, fazla veya yanlış kelime bulunmaktadır. Benzer yanlışlar aşağıda gelen risaleyi içeren diğer üç nüshada da mevcut olduğu için bu nüshalar mukabelede kullanılmamıştır.

8.2.13. Süleymaniye Kütüphanesi, Hasan Hüsnü Paşa, nr. 509 (vr. $\left.28^{\mathrm{a}}-30^{\mathrm{a}}\right)$

Risalenin müstensihi mecmua içindeki diğer bazı risalelerin sonunda yer alan kayda göre Sipâhî Ahmed b. Süleyman isimli kişi olup risalelerin istinsah tarihi Rebiülâhir 1108'dir (Kasım 1696). Varakları kırmızı cetvellidir. Risalenin adı "Hâzihî risâle fì beyâni mesâili ashâbil-Hanefiyye li-Ali Çelebi eş-şehîr bi-Hinnâîâde" olarak kayıtlıdır.

8.2.14. Süleymaniye Kütüphanesi, Hasan Hüsnü Paşa, nr. 1192 (vr. $\left.63^{\mathrm{a}}-65^{\mathrm{a}}\right)$

Risale Muhammed Eyyûbî isimli biri tarafından 10 Cemâziyelâhir 1148 (28 Ekim 1735) tarihinde istinsah edilmiştir. Varakları kırmızı cetvellidir. Risalenin adı "Risâle fî beyâni mesâili ashâbil-Hanefiyye li-Hinnầzâde Ali Çelebi" olarak kayıtlıdır.

\subsubsection{5. İzmir Millî Kütüphane, nr. 1866 (vr. $58^{\mathrm{b}}-60^{\mathrm{a}}$ )}

Müstensihi ve istinsah tarihi bilinmeyen bu nüsha geç döneme aittir. Risalenin adı nüshada, "Risâle fî beyâni ıstılâhâtìl-mütedâvile fî kütübill-fikh limevlânâ Ali Çelebi eş-şehîr bi-Hinnâîzâde" olarak kayıtlıdır. Risalenin başında aşağıda gelecek olan Konya Bölge Yazma Eserler (nr. 3263), İstanbul Üniversitesi (Nadir Eserler, nr. AY6405) ve Manisa İl Halk (nr. 2226) kütüphanelerindeki nüshalarda da yer alan şu mukaddime cümlesi bulunmaktadır: 


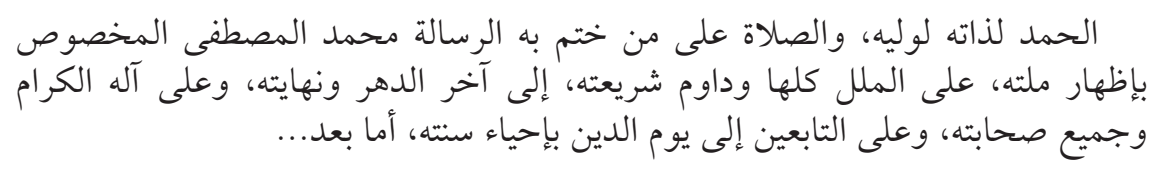

\subsection{Risalenin Müstakil İkinci Versiyonunu İçeren Nüshalar, Genel Rumuz $\{$ ج\}}

Risalenin bu versiyonunda müstakil ilk versiyona ait Diyanet İşleri Başkanlığı nüshasında (nr. 1212) iki ayrı parça halinde yer alan bilgilerin risalenin ilgili yerlerine konulup birleştirildiği tespit edilmiştir. Ayrıca ilk versiyonda bulunan “ cümlesinin risalenin bu ikinci versiyonu ile aşağıda gelecek olan üçüncü ve son versiyonunda yer almadığı tespit edilmiştir.

و وإمَّام " Risalenin müstakil ikinci versiyonu ile üçüncü versiyonu arasında

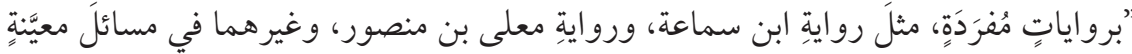
cümlesinin takdimi ile anlama tesir etmeyen birkaç kelimenin eklenip çıkarılmasından başka bir fark bulunmadığı için tahkikte risalenin son versiyonu olduğunu düşündügümüz üçüncü versiyona ait nüshalar kullanılmış, bu ikinci versiyonun farkları dipnotta $\{$ \} genel rumuzuyla gösterilmiştir. Birçoğu daha eski tarihli olduğu halde risalenin son versiyonunu temsil etmediği kanaatine vardığımızdan tahkikte kullanmadığımız risalenin bu müstakil ikinci versiyonuna ait tespit edebildiğimiz on nüsha şunlardır:

\subsubsection{Süleymaniye Kütüphanesi, Ayasofya, nr. 3401 (vr. $\left.1^{\mathrm{b}}-2^{\mathrm{a}}\right)$, Rumuz "ص"}

Kefevînin Ketâib'ine ait bir nüshanın başında alan yer alan bu risalenin ferağ kaydı yoktur. Risalenin kenarında ve sonunda daha önceki Mihrişah Sultan ve Nuruosmaniye nüshalarında da yer alan açıklama ve müellifin minhüvât kaydı bulunmaktadır. ${ }^{39}$ Risalenin adı “Tabakātül-mesâil li-Ali Çelebi İbni Hinnâ̂̀" olarak kayıtlıdır.

\subsubsection{Süleymaniye Kütüphanesi, Esad Efendi, nr. 3652}

$$
\text { (vr. } \left.110^{\mathrm{b}}-111^{\mathrm{a}}\right)
$$

Risalenin istinsah tarihi olmasa da mecmuada aynı hatla yazılmış diğer bazı risalelerin ferağ kaydında $\left(147^{\mathrm{b}}, 149^{\mathrm{a}}\right) 988$ Muharrem başlarında (Şubat 1580) yazıldıkları bilgisi yer almaktadır. Bu tarihe göre risalenin bu versiyonu, müellifinin vefat tarihi olan 979'dan (1572) yaklaşık on yıl kadar sonra yazılmış olan en eski tarihli nüsha olma özelliğine sahiptir. Risalenin

$39 \mathrm{Bu}$ açıklamalar ve minhüvât notu risalenin son versiyonuna ait tahkikli metnin dipnotuna eklenmiştir. 
adı yoktur, müellifin adı ise risalenin sonunda kısaca "Ali el-Hakīr" şeklinde kayıtlıdir.

\subsubsection{Süleymaniye Kütüphanesi, Cârullah Efendi, nr. 847} (vr. $\left.139^{\mathrm{a}}-139^{\mathrm{b}}\right)$

Risalenin ferağ kaydı yoktur. Kenarında risaledeki konularla ilgili beş tane matlap kaydı bulunmaktadır. Risalenin adı "Tabakātü’l-mesâil li-Ali Çelebi İbni Hinnầ’” olarak kayıtlıdır.

\subsubsection{Süleymaniye Kütüphanesi, Şehid Ali Paşa, nr. 2811 (vr. $\left.177^{\mathrm{a}}-178^{\mathrm{a}}\right)$}

Risalenin ferağ kaydı yoktur. Mecmuada yer alan diğer bazı risalelerin sonunda $999\left(247^{\mathrm{b}}\right)$ ve Muharrem 1003 (239 $)$ tarihli istinsah kayıtları bulunmaktadır. Nüshada risalenin adı zikredilmeden, "Merhûm ve mağfûrün leh Ali Çelebi hazretlerinindir” denilmekle yetinilmiştir.

\subsubsection{Süleymaniye Kütüphanesi, Lala İsmâil, nr. 706}

$$
\text { (vr. } \left.226^{\mathrm{b}}-227^{\mathrm{a}}\right)
$$

Risalenin bu versiyonu Câmiu’n-nukūl adlı Mülteka'l-ebhur şârihi Üsküp kadısı Tellakzâde Hâfız Hacı Mustafa Efendi tarafından kaydedilen fevâidlerin, kendi hattıyla istinsah edilen kitapların ve risalelerin bulunduğu bir mecmua içinde yer almaktadır. Risalenin ferağ kaydı yoktur. Risalenin adı "Risâle fî tabakāti mesâilil-Hanefiyye lì-mevlâ Ali b. Emrullah eş-şehîr biKınalızâde" olarak kayıtlıdır.

\subsubsection{Beyazıt Devlet Kütüphanesi, Veliyyüddin Efendi, nr. 1606 $\left(\right.$ vr. $\left.50^{\mathrm{a}}-51^{\mathrm{a}}\right)$}

Ferağ kaydı olmayan risalenin bu versiyonu bir önceki Lala İsmail nüshasındaki versiyonu ile benzerlik göstermektedir. Her ikisindeki hatalar aynı olduğu gibi risalenin adı da aynı şekilde, "Risâle fî tabakāti mesâilil-Hanefiyye li’l-mevlâ Ali b. Emrullah eş-şehîr bi-Kınalızâde” olarak kaydedilmiştir.

\subsubsection{Konya Bölge Yazma Eserler Kütüphanesi, nr. 3263 (vr. $\left.75^{\mathrm{b}}-76^{\mathrm{b}}\right)$}

Risalenin istinsah tarihi belli olmamakla birlikte mecmua içindeki diğer bir risalenin ferağ kaydı $\left(56^{\mathrm{b}}\right)$ Şevval 1084 olarak düşülmüştür. Risalenin adı "Risâle fill-ıstılâhâtil-mütedâvile fî kütübi'l-fikh li-Ali Çelebi eş-şehîr biHinnầzâde rahimehullahu teâlâ" olarak kayıtlıdır. 


\subsection{8. İstanbul Üniversitesi Kütüphanesi, Nadir Eserler, nr. AY6405 (vr. $\left.18^{\mathrm{b}}-20^{\mathrm{b}}\right)$}

Nüshanın sonunda yer alan ferağ kaydına göre $\left(128^{\mathrm{b}}\right)$ risalenin içinde bulunduğu bu mecmuanın istinsahı 1182 yılında tamamlanmıştır. Risalenin adı "Risâle fill-ıstılâhâti'l-mütedâvile fî kütübil-fikh li-Ali Çelebi eş-şehîr biHinnâizâde rahimehullahu teâlâ" olarak kayıtlıdır.

\subsubsection{Manisa İl Halk Kütüphanesi, nr. $2226\left(\text { vr. } 7^{\mathrm{a}}-8^{\mathrm{a}}\right)^{40}$}

Risalenin ferağ kaydı yoktur. Risalenin adı "Risâle fî beyâni ıstılâhâtìlmütedâvile fî̀ kütübil-fikh li-Ali el-Çelebi eş-şehîr bi-Hinnâîzâde rahmetullahi aleyh" olarak kayıtlıdır.

\subsubsection{Millet Kütüphanesi, Reşid Efendi, nr. 1032 (vr. $159^{\mathrm{a}}-161^{\mathrm{b}}$ )}

Risalenin ferağ kaydı yoktur. Aynı hatla yazılmış bir önceki Kemalpaşazâde’nin Tabakātü'l-fukahâ adlı risalesinin $\left(157^{\mathrm{a}}-158^{\mathrm{a}}\right)$ istinsah tarihi 1117'dir (1705-6). Varakları kırmızı cetvelli olup risalenin adı sadece mecmuanın içindeki risalelerin zikredildiği zahriyesinde "Tabakāt Ali Çelebi" olarak kaydedilmiştir.

\subsection{Risalenin Müstakil Üçüncü Versiyonunu İçeren Nüshalar, Genel Rumuz $\{2\}$}

Yukarıda ifade edildiği üzere nüshanın üçüncü ve son versiyonunda bir önceki versiyonda yer alan bir cümlenin yeri değiştirilmiş, anlama tesir etmeyen bazı kelimeler eklenmiş, çıkarılmış veya değiştirilmiştir. Son versiyonuna ait olduğunu düşündüğümüz için tahkikte kullanmaya karar verdiğimiz risalenin bu versiyonunu içeren nüshalardan tespit edebildiklerimiz şunlardır:

8.4.1. Süleymaniye Kütüphanesi, Pertev Paşa, nr. 621 (vr. 42 $\left.{ }^{\mathrm{a}}-43^{\mathrm{a}}\right)$, Rumuz “"ॄ”

Mecmuanın istinsah tarihi 1015'tir (1606). Varakları kırmızı cetvelli olup bazı kelimeler eksiktir. Risalenin adı kırmızı mürekkeple, "Risâletüttabakāt mine'l-mesâil fî̀ kütibihim muhtelitaten gayra mümeyyetezin" șeklinde yazılmıştır.

\subsubsection{Kayseri Râş̧id Efendi Kütüphanesi, nr. 241 (vr. $\left.92^{\mathrm{a}}-93^{\mathrm{a}}\right)$, Rumuz “,”}

Risalenin ferağ kaydı yoktur. Mecmua içinde aynı hatla yazılmış bir sonraki 12 Rebîülevvel 1100 (4 Ocak 1689) istinsah tarihli risalenin müstensihi

40 Bu nüshada varak numarası bulunmadığ verilmiștir. 
Derviş İbrâhim’dir. Risalenin adı “Risâle tabakätü’l-mesâil li'l-merhûm Ali Çelebi" olarak kayıtlıdır.

8.4.3. Süleymaniye Kütüphanesi, Şehid Ali Paşa, nr. 653 (vr. $\left.182^{a}-183^{a}\right)$, Rumuz “ه”

Risalenin müstensihi yukarıda adı geçen Derviş İbrâhim b. Süleyman olup istinsah tarihi 26 Rebîülevvel 1102 (28 Aralık 1690) Çarşamba gecesidir. Varakları kırmızı cetvellidir. Risalenin adı "Risâle tabakātil-mesâil lìl-mevlâ el-merhûm Ali Çelebi" olarak kayıtlıdır.

8.4.4. Süleymaniye Kütüphanesi, Şehid Ali Paşa, nr. 2831 (vr. $56^{\mathrm{b}}-57^{\mathrm{b}}$ )

Risalenin istinsah tarihi 1082'dir (1671). Risalenin adı “Tabakātü’l-mesâil lì-merhûm müftî Ali Çelebi rahmetullahi aleyh" olarak kayıtlıdır. Risalenin yer aldığı bu nüsha içerdiği hatalar sebebiyle mukabelede kullanılmamıștır.

8.4.5. Süleymaniye Kütüphanesi, Şehzade Mehmed, nr. 110 (vr. $105^{\mathrm{b}}-107^{\mathrm{b}}$ )

Risalenin ferağ kaydı yoktur. Nüshada ne risalenin ne de müellifin adı yer almaktadır. Risalenin yer aldığı bu nüsha içerdiği hatalar sebebiyle mukabelede kullanılmamıştır.

\subsection{Risalenin Müstakil Birinci Versiyonu ile Son Versiyonunu Telfik Eden Nüshalar}

Nüshalar üzerinde yaptığımız karşılaştırmalar sonucunda risalenin aşağıdaki iki nüshada yer alan versiyonunun, risalenin müstakil birinci ve ikinci versiyonlarının bir telfiki olduğu kanaati hasıl olduğundan risaleyi içeren bu iki nüsha tahkikte kullanılmamıştır.

\subsubsection{Süleymaniye Kütüphanesi, Fâtih, nr. 5539 (vr. $19^{\mathrm{b}}-20^{\mathrm{b}}$ )}

Ferağ kaydı olmayan risalenin bu versiyonunda, müstakil birinci versiلكن المقال الشائع أن" yonda bulunup ikinci ve üçüncü versiyonda bulunmayan "يكون قول الثالثة أو قول بعضطم cümlesi ile yine birinci versiyonda yer alan bazı kelimeler bulunmamaktadır.

\subsubsection{Diyanet İşleri Başkanlığı Kütüphanesi, nr. 2868 (vr. $\left.551^{\mathrm{b}}-552^{\mathrm{a}}\right)$}

Oldukça geç tarihe ait olan risalenin bu versiyonu 10 Cemâziyelevvel 1270 'te (8 Şubat 1854) (Kayseri) Ağırnaslı Mesud tarafından yazılmıştır. Bu versiyonda risalenin müstakil birinci versiyonunda bulunup ikinci ve üçün"لكن المقال الشائع أن يكون قول الثالثة أو قول بعضهم" cü versiyonda bulunmayan ifadesi ile müstensih tasarrufundan kaynaklandığı tahmin ettiğimiz risalenin diğer versiyonlarında bulunmayan bazı kelimeler vardır. 


\subsection{Tabakātü’l-mesâil Versiyonları Şeması}

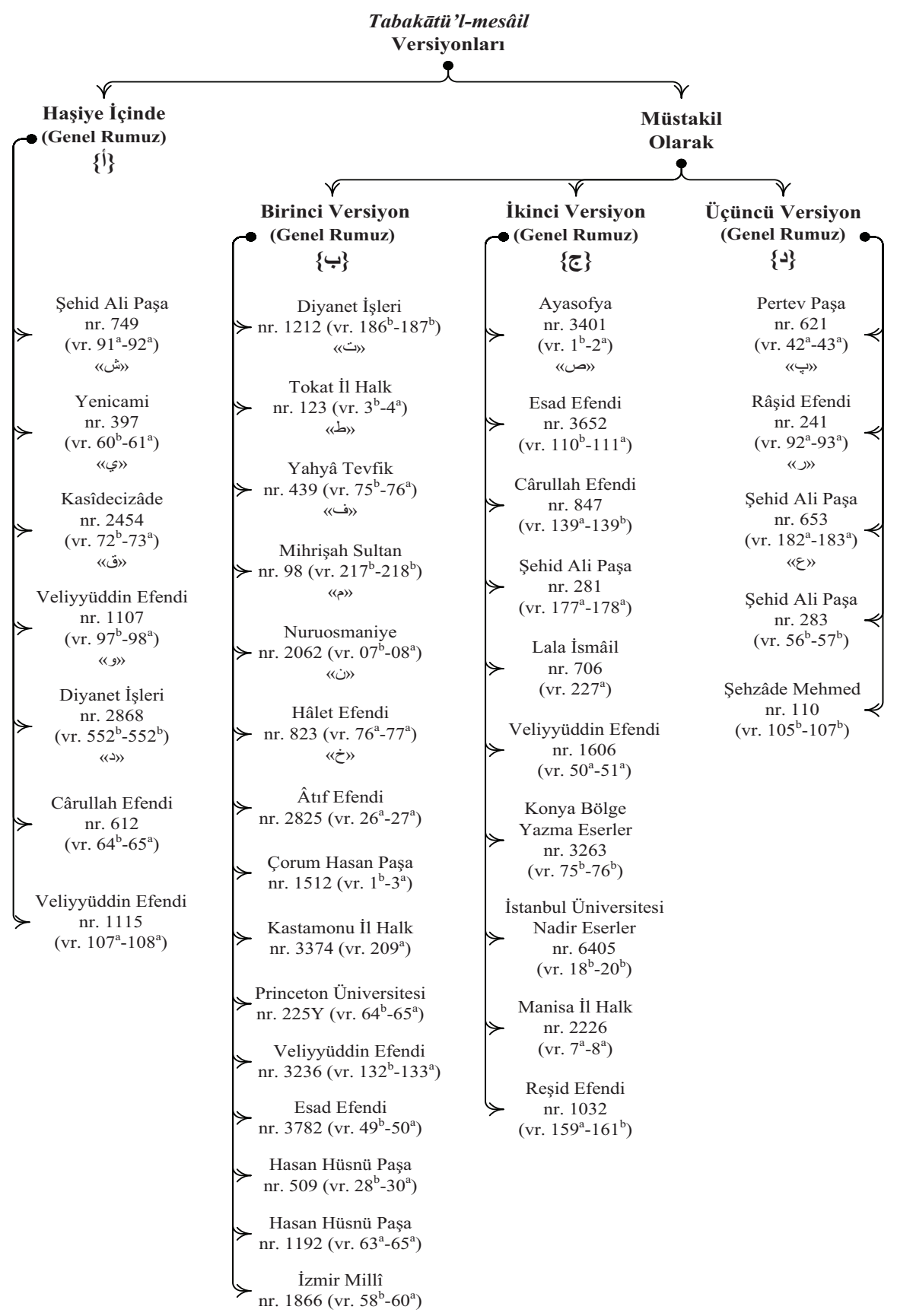




\section{Değerlendirme}

Geç döneme ait bu risalede Kınalızâde Ali Efendi Hanefî mezhebi mesâilini bilgi ve kaynak değeri açısından üç kısımda ele alıp her bir kısımda yer alan mesâili tanımlamıştır. Kınalızâde’nin özellikle zâhirür-rivâye ve gayru zâhirir-rivâye kavramları hakkında ortaya koyduğu tanımlarla bunlara örnek olarak zikrettiği eserlerin erken dönemde aynı konularda verilen bilgilerden mahiyet ve kaplam açısından farklılaştığı görülmektedir. Makalenin bu bölümünde risale bu iki kavram açısından kısaca değerlendirilecektir. ${ }^{41}$

\subsection{Mesâilü'l-usûl ile Zâhirü'r-rivâyenin Mahiyeti}

Kınalızâde Ali Efendi’nin yaptığı tanıma göre mesâilü’l-usûll ile zâhirürrrivâye kavramları eş anlamlı olup mesâilül-usûl (kısaca usul); zâhirür rivâyenin diğer eserleri el-Câmiu's-sagìr, el-Câmiu'l-kebîr ve ez-Ziyâdât'ı da içine almaktadır. Erken dönemde ise usul; zâhirür r-rivâyeden daha dar bir anlam ifade etmektedir. Bu iki kavramın mahiyet ve kaplam açısından genişlemesini şu şekilde özetleyebiliriz: ${ }^{42}$

Hanefî mezhebinde V. (XI.) yüzyllın ortalarına kadar Cessâs (ö. 370/981), Kudûrî (ö. 428/1037), Saymerî (ö. 436/1045) ve Nâtıfî (ö. 446/1054) gibi mezhebin doğduğu Irak bölgesi Hanefî fakihlerinin kitaplarında mezhep imamlarından aktarılan mesâil ile bunların yer aldığı eserleri ifade etmek üzere dört temel kavramın kullanıldığı görülmektedir.

Usul: Ebû Hanîfe'nin meclisinde kayda geçilip daha sonraları Şeybânî tarafından düzenlenen ve daha çok el-Asl/el-Mebsût ismi ile bilenen eser ve bu eserin içinde yer alan mesâili ifade etmekte kullanılan kavram.

Câmiayn/Cevâmi : Şeybânînin fikhın hemen bütün konularını cemeden eserlerini ifade etmekte kullanılan kavram. Şeybânînin câmi‘ türünden iki eseri vardır: el-Câmiu's-sagìr, el-Câmiu'l-kebîr. ${ }^{43}$

41 Buradaki değerlendirme, daha önce yaptığımız şu çalışmadan bazı değişikliklerle birlikte özetlenmiştir; daha geniş bilgi için bk. Ençakar, "Bilgi ve Kaynak Değeri Açısından Hanefî Mezhebinde Mesâil Tasnifi Kınalızâde Ali Efendi Örneği”, s. 509-22.

42 Zâhirürr-rivâye ve gayru zâhirirr-rivâye kavramlarının gelişim süreci ve içerdiği eserler hakkında geniş bilgi için bk. Ençakar, Hanefî Mezhebi Nevâdir Literatürü, s. 32-76.

43 Şeybânînin bu iki eserini ifade etmek üzere genelde câmiayn ifadesi tercih edilmekle birlikte cevâmi' ifadesi de kullanılmaktadır (bk. Hâkim eş-Şehîd, el-Kâfî̀, Süleymaniye

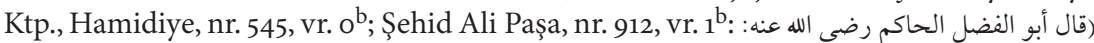

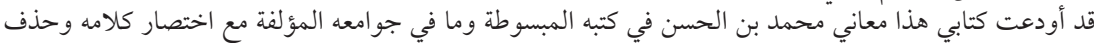
Diğer kavramlar gibi çoğul kipinde olması açısından cevâmi ifadesi tercih edilebilir. 
Emâlî: Ebû Yûsuf ve Şeybânînin talebelerine yazdırmak suretiyle oluşturdukları kitapları ve bu kitaplar içinde yer alan mesâili ifade etmekte kullanilan kavram.

Nevâdir: Özellikle Ebû Yûsuf ve Şeybânînin usulde yer almayan mesâili ve bu mesâilin genellikle talebeleri tarafından toplanmasıyla meydana gelen eserleri ifade etmekte kullanılan kavram.

Bu dört kavramdan usulün erken dönem Hanefî fakihleri arasında neye tekabül ettiğine dair Kudûrînin verdiği bilgiler önemlidir. O, Kerhînin (ö. 340/952) el-Muhtasar'ına yazdığı şerhte usul adı verilen mesâil ile bunların yer aldığı eserlerin nasıl tedvin edildiğine dair şunları aktarmaktadır:

Ebû Hanîfe bu mezhebi ashabıyla istişare ederek kurmuştur. Meseleleri kendi başına ortaya koymamıştır. Meseleleri tek tek ashabına açıp onların görüşlerini almış, bu görüşlerden hangisinin doğru olduğu ortaya çıkana kadar onlarla tartışmış, Ebû Yûsuf da kabul edilen görüşü kayda geçerek usulün tamamını oluşturmuştur. ${ }^{44}$

Kudûrînin bu ifadesine göre usul, Ebû Hanîfe'nin meclisinde tartışıllip kayda geçirilen mesâil ve bunların yer aldığı kitapları ifade etmektedir. ${ }^{45}$ Usul olarak ifade edilen bu mesâilin, Ebû Hanîfe'nin meclisinde ilk yazıldığı haliyle "rûznâmçe" ve "divan" adı verilen defterlere tasnif edilmeden kaydedilen fikıh mesâilinden oluştuğu anlaşılmaktadır. ${ }^{46}$ Serahsînin (ö. 483/1090?) ifadesiyle, "Ebû Hanîfe'nin ortaya koyduğu mesâili tasnif etmeye kendini adayan kişi Şeybânîdir." ${ }^{77}$ Şeybânî, Ebû Hanîfe’nin görüşlerinin yanına kendisi, Ebû Yûsuf ve çok az yerde Züfer'in görüşleriyle bazı tahriçleri de ekleyerek usul olarak isimlendirilen kitapları yeniden tasnif etmiştir. Usul V. (XI.) asırdan itibaren el-Asl/el-Mebsût adıyla anılmaya başlanmış ve büyük bir bölümü günümüze kadar gelmiştir. el-Asl’ın mevcut nüshalarından yapılan son neşrine göre eserin içinde Kitâbü's-Salât ile başlayıp Kitâbüll-Gasb ile sona eren elli yedi kitap vardır. Eserin bazı bölümleri kayıptır. ${ }^{48}$

Ebû Hanîfe'nin meclisinde yazılan ve daha sonra Şeybânî tarafından yeniden tasnif edilen bu mesâilden erken kaynaklarda usul veya kütüb diye çoğul kipiyle bahsedilmesi ilk zamanlar bu meseleleri içeren kitapların bir-

44 Kudûrî, Şerhu Muhtasari'l-Kerhî, vr. ob.

45 Kudûrînin usul adı verildiğini söylediği bu mesâilin Ebû Hanîfe’nin meclisinde kayda geçirildiğini gösteren başka nakiller için bk. İbn Ebü'l-Avvâm, Fezâilü Ebî Hanîfe, s. 341; Saymerî, Ahbâru Ebî̀ Hanîfe, s. 74, 113, 156.

46 Bk. İbn Ebü'l-Avvâm, Fezâilü Ebî Hanîfe, s. 308, 341-42.

47 Serahsî, el-Mebsût, I, 3.

48 Bk. Boynukalın, el-Asl: Mukaddime, s. 75-8o. 
birinden ayrı olduğunu gösterir. Bibliyografya eserlerinde buna delalet eden ifadeler bulunmaktadır. ${ }^{49}$

Usul hakkında kaynaklarda yer alan bu bilgiler ışığında, Hanefî mezhebinde usulü, "Ebû Hanîfe'nin meclisinde tartışılıp kayda geçilen ve daha sonra Şeybânî tarafından yeniden tasnif edilip bugün $e l$-Asl adıyla bilinen kitabı ve içinde yer alan mesâili ifade etmekte kullanılan bir kavram" olarak tanımlamak mümkündür.

Kaynaklarda usul ile zâhirür-rivâyenin diğer eserlerini birbirinden ay1ran ve bunların aynı olmadığını gösteren nakiller de mevcuttur. Saymerî, Hanefî fakihlerinden Ebû Zekeriyyâ ed-Darîr için, "Usul, câmiayn ve nevâdiri bilirdi”, ${ }^{50}$ Ali er-Râzî için de, "Usul ve el-Câmiu'l-kebîr'den bazı meselelere tenkidi vardı" ${ }^{51}$ ifadesini kullanır. Bu bilgilerden hareketle erken dönem Hanefî fukahası arasında kullanılan usul kavramının, geç dönemde bu kavrama dahil edilen el-Câmiu's-sagìr ve el-Câmiu'l-kebîr gibi diğer zâhirürr-rivâye eserlerini içermediğini söyleyebiliriz.

V. (XI.) yüzyılın başından itibaren mezhebin mesâil tabakasını ifade etmek üzere iki üst şemsiye kavram; zâhirürr-rivâye ve gayru zâhirir-rivâye kavramları kullanıma girmiş ve böylece usul/el-Asl ile el-Câmiu’s-sagìr, elCâmiu'l-kebîr (cevâmi') zâhirür-rivâye üst kavramı; emâlî ile nevâdir ise gayru zâhirir-rivâye üst kavramı altında toplanmıștır. Ayrıca zâhirür-rivâye eserleri arasında Şeybânînin diğer iki eseri ez-Ziyâdât ile es-Siyerü̉l-kebîr de zikredilmeye başlamıştır.

VIII. (XIV.) yüzyıldan itibaren bu yeni kavram çiftinden zâhirürrivâyenin; kavramın altında yer alan usul terimi ile eş anlamlı olarak kullanılmaya başlandığı anlaşılmaktadır. Mesela İtkānî (ö. 758/1357), usulden maksadın el-Asl, el-Câmiu's-sagìr, el-Câmiu'l-kebîr ve ez-Ziyâdât olduğunu ifade etmiş, ${ }^{52}$ başka bir yerde de bunlara zâhirürr-rivâye denildiğini söylemiş ${ }^{53}$ ve böylece usul ile zâhirürr-rivâyenin aynı şey olduğunu açıcça dile getirmiştir. İtkānî ile aynı dönem ve bölgede yaşamış olan Bâbertî de (ö. 786/1384) -muhtemelen İtkānîden alarak- aynı açıklamayı yapmıştır. Daha sonra Bedreddin el-Aynî de (ö. 855/1451) usulü Bâbertî gibi açıklamış, ${ }^{54}$ risalenin kay-

49 Bk. Nedîm, el-Fihrist, II, 22; Kâtib Çelebi, Keş̧ü̈z-zunûn, II, 1581; ayrıca bk. Boynukalın, el-Asl: Mukaddime, s. 115-16; Bedir, Buhara Hukuk Okulu, s. 65-66.

50 Saymerî, Ahbâru Ebî Hanîfe, s. 173.

51 Saymerî, Ahbâru Ebî Hanîfe, s. 164.

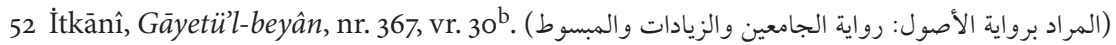

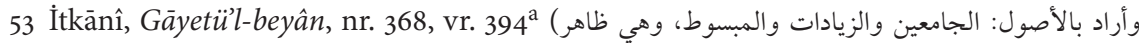

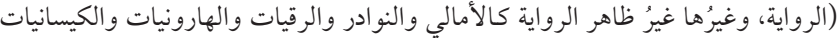

54 Bâbertî, el-İnâye, VIII, 371; Aynî, el-Binâye, IX, 460. 
nakları kısmında geçtiği üzere aynı bölge ve dönemden İbn Kutluboğa da (ö. 879/1474) aynı ifadeleri kullanmıştır. İtkānî, Bâbertî ve Aynî bu açıklamalarını yaptıkları yerde gayru zâhirir-rivâye eserlerini de "nevâdir, emâlî, el-Keysâniyyât, el-Hârûniyyât, er-Rakkıyyât" olarak saymışlardır. Seyyid Şerîf el-Cürcânî (ö. 816/1413) ile Taşköprizâde (ö. 968/1561) bu son eserlere elCürcâniyyât'ı eklemişlerdir. ${ }^{55}$

İtkānî, Bâbertî, Aynî ve İbn Kutluboğa’dan hemen sonra Kınalızâde Ali Efendi de usul ile zâhirürr-rivâye kavramlarını onların yaptığı gibi eş anlamlı olarak tanımlamıştır. Kanaatimizce usulü oluşturan kitapların zamanla bir kitapta toplanıp el-Asl diye anılmasının bir sonucu olarak erken dönem kaynaklarında geçen usul kavramının içi el-Asl'ın yanına el-Câmiu's-sagìr ve elCâmiu'l-kebîr gibi zâhirürr-rivâyenin diğer eserleri de eklenerek doldurulmuş ve böylece usul mahiyet ve kaplam açısından genişletilerek zâhirürr-rivâye ile eş anlamlı hale getirilmiştir. Nitekim Taşköprizâde zâhirürr-rivâye kitaplarından sadece el-Mebsût'u el-Asl diye; el-Mebsût ile el-Câmiayn (el-Câmiu's-sagìr, el-Câmiu'l-kebîr) ve Ziyâdât' 1 ise rivâyetü'l-usûl diye isimlendirme noktasında fukaha arasında ittifak olduğunu aktarmaktadır. ${ }^{56}$

İtkānî, Bâbertî, Aynî ve İbn Kutluboğa gibi isimlerin öncülüğünde mahiyet ve kaplam açısından genişlediği anlaşılan usul kavramının bu yeni anlamı Kınalızâde’nin risalesiyle Hanefî çevrelerinde hızla yayılmış ve bu risaleden doğrudan veya dolaylı yolla nakille konuya dair bilgi veren Kefevî, Temîmî, Nablusî, Hamevî, Pîrîzâde, İbn Âbidîn, Leknevî ve Mercânî gibi meşhur simalar bu yeni tanım ve tasnifin yerleşmesinde önemli rol oynamışlardır. Bu konuda yapılan akademik çalışmalarda yer alan tanımların Kınalızâde’nin verdiği tanımlara göre şekillenmesinde, adı geçen kişilerin risaledeki tanımları olduğu gibi benimseyip aktarmalarının belirleyici olduğu söylenebilir.

\subsection{Mesâilü’n-nevâdir ile Gayru zâhiri'r-rivâyenin Mahiyeti}

Kınalızâde Ali Efendi mesâilü̉n-nevâdirden bahsettiği ikinci başlık altında mezhep imamlarından aktarılan zâhirürr-rivâye dışındaki mesâili üç grupta toplayıp bunların hepsini nevâdir olarak isimlendirmiş ve ilk iki grupta zikrettiği Şeybânînin diğer eserlerine aynı zamanda gayru zâhirirr-rivâye denildiğini belirterek tıpkı kendisinden öncekilerin mesâilül-usûl ile zâhirürr-rivâyeyi eş anlamlı olarak tanımladığı gibi kendisi de nevâdir ile gayru zâhirirr-rivâyeyi eş anlamlı olarak tanımlamıştır. Böylece X. (XVI.) yüzyılın ikinci yarısında

55 Bk. Cürcânî, et-Ta'rîfât, s. 32; Taşköprizâde, Miftâhu's-saâde, s. 638. 56 Bk. Taşköprizâde, Miftâhu's-saâde, s. 638. 
usul ile zâhirür-rivâye, nevâdir ile de gayru zâhirir-rivâye kavramları eş anlamlı olarak tanımlanmış ve mahiyet ve kaplam açısından erken dönemdekinden daha geniş bir usul ve nevâdir tanımı geliştirilmiştir.

Yukarıda geçtiği üzere gayru zâhirìr-rivâye bir üst kavram olup altında iki farklı telif türü olan emâlî ve nevâdir yer almaktadır. Dolayısıyla nevâdir; emâlî eserlerini de içine alacak kadar geniş bir kavram değildir.

Erken dönemdeki kullanımına uygun olarak nevâdiri, "Hanefî mezhebi imamlarının usulde yer almayan mesâili ile bu mesâilin genelde talebeler tarafından kayıt altına alınması suretiyle oluşan eserleri ifade etmekte kullanılan bir kavram" olarak tarif edebiliriz.

Emâlîyi Hanefî mezhebi özelinde Kınalızâde Ali Efendinnin risalesinde de ifade ettiği üzere, "bir âlimin herhangi bir metne bağlı kalmaksızın ilgili konu hakkında kendi bilgi ve birikiminden hareketle talebelerine yazdırdığ 1 mesâilden oluşan metinleri ifade etmekte kullanılan bir kavram" olarak tanımlayabiliriz.

Hanefî mezhebinde emâlî denilince kastedilen daha çok Ebû Yûsuf ve Şeybânî tarafından, -erken dönemdeki anlamıyla- usule bağlı kalmadan hem usulde yer alan mesâili hem de orada geçmeyip ilk defa dile getirilen nevâdir olarak adlandırılan mesâili içerecek tarzda imla ettirilen eserlerdir.

Kınalızâde Ali Efendi mesâilün-nevâdir ve gayru zâhirir-rivâye olarak tanımladığı ikinci grup mesâili kendi içinde üçe ayırmış ve ilk kısımda, "Şeybâni’nin zâhirür-rivâye eserleri dışında telif ettiği eserler" diyerek, erRakkıyyât, el-Keysâniyyât, el-Cürcâniyyât ve el-Hârûniyyât' ' bu kısımda zikretmiştir. Bu eserlerin erken dönemde nevâdir eserleri arasında sayıldığına dair bir bilgiye ulaşamadık. er-Rakkıyyât daha çok Şeybânînin Rakka’da kadı iken yazdırdığı mesâili içeren bir emâlî eseri olarak bilinmektedir. el-Keysâniyyât ise talebesi Ebû Saîd Şuayb b. Süleyman el-Keysânî (ö. 204/820) tarafından rivayet edilen el-Emâlî̀si olup çok az bir kısmı günümüze ulaşmış ve yayımlanmıştır. ${ }^{57}$ Diğer taraftan Kınalızâde Ali Efendỉnin Şeybânîye ait olduğunu söylediği el-Cürcâniyyât ile el-Hârûniyyât'in Şeybânîye ait olmadı̆̆g, elCürcâniyyât'in Ebû Yûsuf'un talebelerinden Ali b. Sâlih el-Cürcânînin Ebû Yûsuf'tan yaptığı nakilleri içeren bir eser, el-Hârûniyyât müellifinin de Hasan b. Ziyâd olduğu Yılmaz tarafından tespit edilmiştir. ${ }^{58}$ Ayrıca Kınalızâde Ali Efendi emâlî eserleri arasında sadece Ebû Yûsuf'un el-Emâlı̀sini zikretmiştir.

57 Cüz' min'lemâlî li-Muhammed, nşr. Hâşim en-Nedvî v.dğr., Haydarâbâd: Matbaatü Dâireti'l-maârifi'l-Osmâniyye, 1407/1986.

$58 \mathrm{Bu}$ iki kitabın gerçek müellifleri hakkındaki Yılmaz’ın tespitleri için bk. İlk Tedvin Döneminde Hanefî Mezhebi Literatürünün Kayıp Eserleri, s. 107-111. 
Oysa Ebû Yûsuf'un el-Emâlîsi kadar meşhur olmasa da Şeybânînin de elEmâlî̉si vardır. Yılmaz, çalışmasında Ebû Yûsuf ve Şeybânînin el-Emâlı̂lerini rivayet eden râvileri tespit etmiştir. Eserler günümüzde kayıp durumdadır. ${ }^{59}$

Kınalızâde Ali Efendi risalede birkaç nevâdir eseri zikretmekle yetinmiştir. Hanefî mezhebi nevâdir literatürüne dair yaptığım çalışmada tespit edebildiğim kadarıyla mezhep içinde Ebû Hanîfe, Ebû Yûsuf, Şeybânî, Züfer ve Muhammed b. Mukātil'in nevâdir rivayetlerini içeren on dokuz nevâdir eseri bulunmaktadır. Mevcut verilere göre İbn Mukātil'in en-Nevâdir'i ise tamamen kendisine sorulan sorulara verdiği cevaplardan müteşekkildir. Eser, bu yönüyle diğer nevâdir eserlerinden ayrılmakta ve mezhep imamları dışında birinin görüşlerinin nevâdir adı altında toplanmasının ilk örneklerinden birini oluşturmaktadır. Bu sebeple İbn Mukātil’e ait görüşleri nevâdir adıyla toplayan bu eserin daha sonraları fetâvâ adıyla bilinecek olan literatüre dahil olduğunu söyleyebiliriz. Nevâdir eserlerinden Muallâ b. Mansûr'a ait Nevâdirü Muallâ müstakil olarak günümüze kadar ulaşmış ve yayımlanmıştır. ${ }^{60}$ Şeybânîye ait Nevâdirü’s-savm ise müstakil olmasa da el-Asl'ın içinde günümüze kadar gelmiştir. ${ }^{61}$ Diğer nevâdir eserlerinin varlığına dair henüz bir bilgi yoktur. ${ }^{62}$

Sonuç olarak Kınalızâde Ali Efendi’nin Tabakātü'l-mesâil adıyla meşhur olan bu risalesi, mezhep mesâiline dair üç başlık altında zikrettiği temel kavramlara getirdiği tanımlar ve bunlara örnek olarak zikrettiği eserler açısından erken dönemle uyuşmayan bazı bilgiler içermekle birlikte Hanefî mezhebi mesâil tasnifine dair yazılmış tespit edilebilen ilk ve tek müstakil risale olması ve konu hakkında oluşan sonraki literatür üzerinde belirleyici bir rol oynaması açısından değerini hâlâ korumaktadır.

59 Geniş bilgi için bk. Yılmaz, İlk Tedvin Döneminde Hanefî Mezhebi Literatürünün Kayıp Eserleri, s. 23-53, 100-106.

6o Furat, Muallâ b. Mansûr'un Nevâdir'i.

61 Bk. Şeybânî, el-Asl, II, 205-10.

62 Nevâdir eserleri hakkında bilgi için bk. Ençakar, Hanefî̀ Mezhebi Nevâdir Literatürü, s. 91-156; a.mlf., "Bir Mezhebin Yitik Kültürü”, s. 1-36. 


\section{Risalenin Üç Farklı Versiyonunun Tahkikli Neşri}

$$
\begin{aligned}
& \text { رسالة } \\
& \text { طبقات المسائل } \\
& \text { قنالي زاده علي هلبي } \\
& \text { (ت مات. }
\end{aligned}
$$

[أُفرِتْتُ من حاشيته على درر الحكام لمنلا خسرو (ت. وقد كتبها شرحا لقول منلا خسرو: ((ولم يذكر حكمه في ظاهر الرواية)]

' مطلب: في بيان كتب ظاهر الرواية وغير ظاهر الرواية وأصحابها\{

إنَّ مسائلَ أصحابنا على ثلاثة أصناف:

الصنف الأول: ما روي عن علمائنا المتقدمين -وهم أصحاب المذهب- أبي حنيفة والإمامين وزفر والحسن بن زياد في الروايات الظاهرة عنهم، أي المتواترة

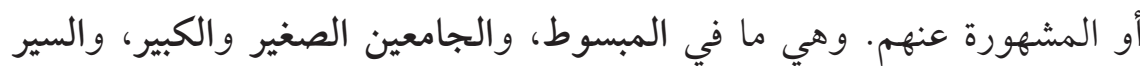

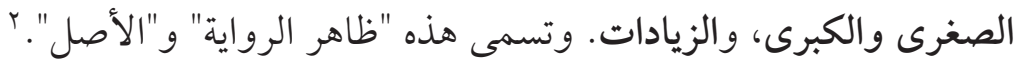

الصنف الثاني: ما روي عنهم برواياتٍ غيرِ ظاهرةٍ، مثل: الجرجانيات

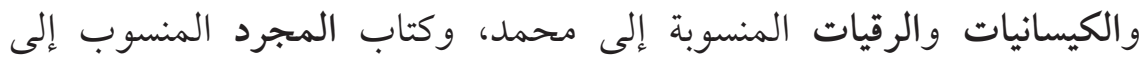
الحسن بن زياد، ورواياتٍ مفردة عنهم، كرواية ابن سماعة والمعلى وغيرهم. و سُمَّيّ هذه "غير ظاهر الرواية" و "النوادر".

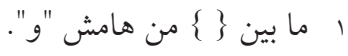

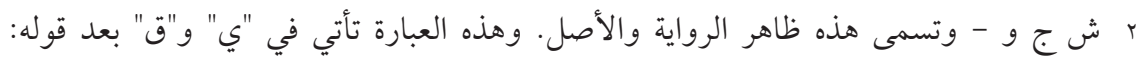

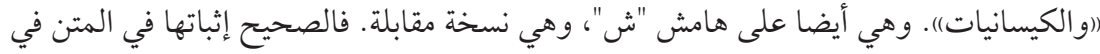

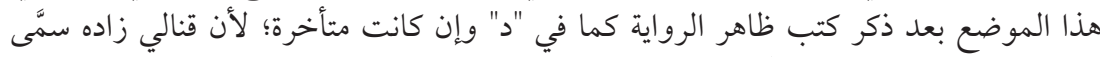

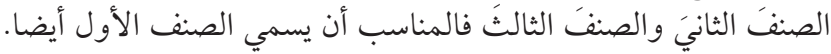


الصنف الثالث: مسائلُ لم تُرْوَ عنهم لا في ظاهر الرواية ولا في غير ظاهر

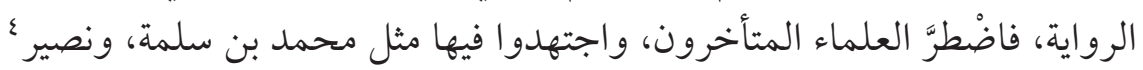

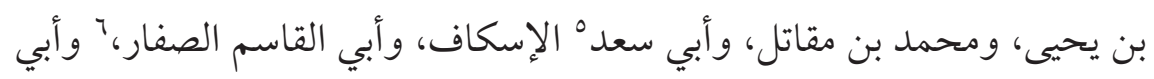
جعفر الهندواني، وأضرابهم.

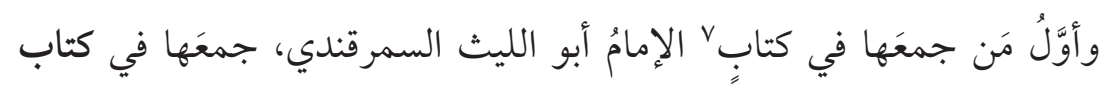

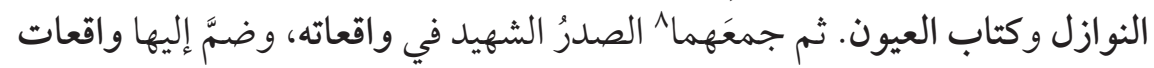

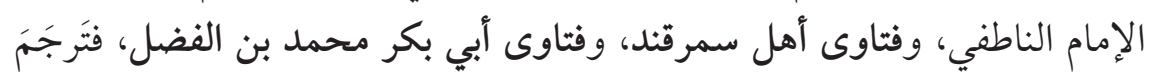

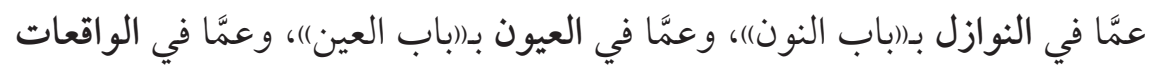

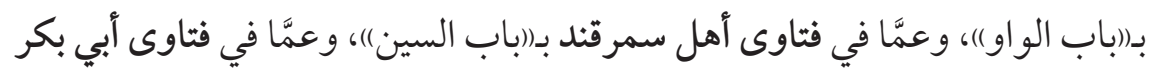

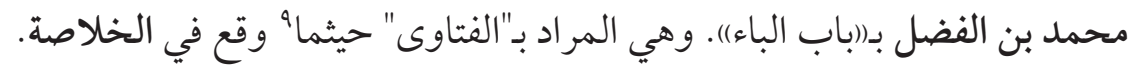

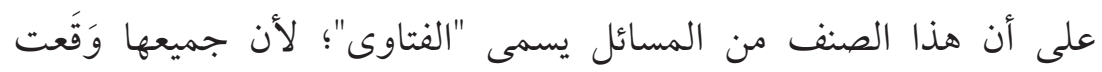

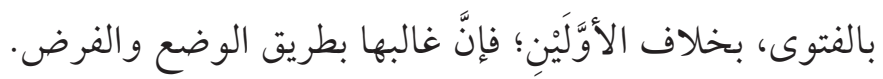

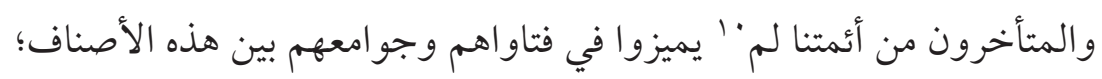

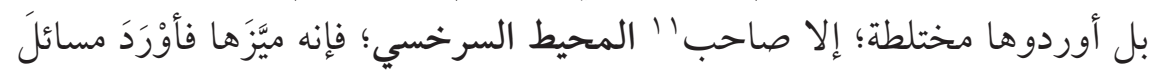

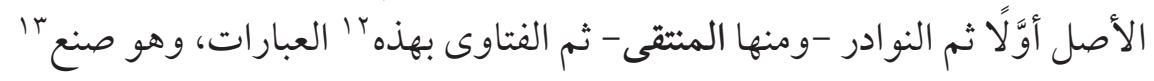
حسن، رحمه الله تعالى.

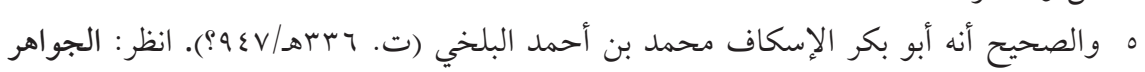

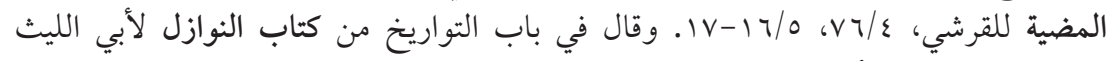

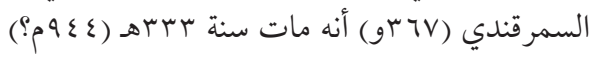

$$
\begin{aligned}
& \text { I ق - الصفار. } \\
& \text { v } \\
& \text { ^ ي ق و : جمعها. } \\
& \text { ه ش و: حيث. }
\end{aligned}
$$

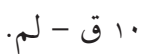

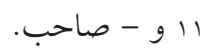

$$
\begin{aligned}
& \text { rir } \\
& \text { rا ش و: صنيع. }
\end{aligned}
$$




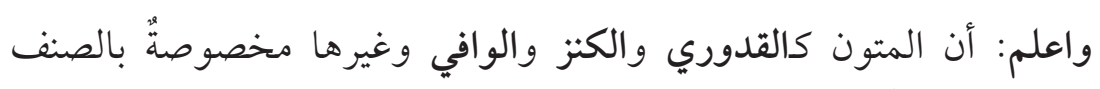

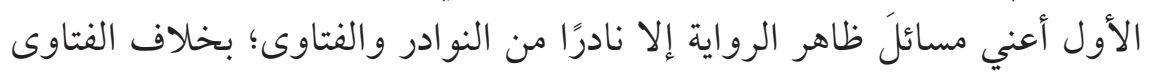

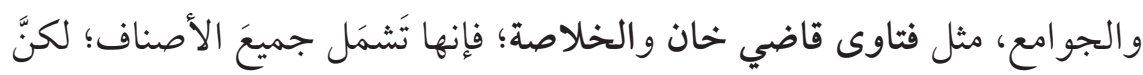
الغالبَ فيها أيضا الصنفُ الأخيرُ.

فاحتفظ بهذه الفوائد؛ فإنها لا توجد لغيرنا، والله الموفق. 


$$
\begin{aligned}
& \text { رسالة } \\
& \text { طبقات المسائل } \\
& \text { قنالي زاده علي گجلبي }
\end{aligned}
$$

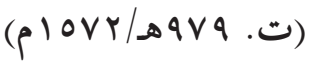

[الإبرازة الأولى من الرسالة مستقلةً، وهي تتألف من قسمين منفصلين]

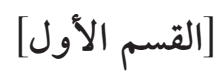

\}مطلب: مِن جمع علي هُلبي حنائي زاده رحمه الله، وقد جمَعها من خط

اعلم -وفَّقك الله- أنَّ مسائلَ أصحابناْ ا رحمهم الله على ثلاثِ طبقاتٍ: الأولى: "مسائل الأصول" وتسمَّى "ظاهر الرواية" أيضا، وهي مسائلُ رُويت

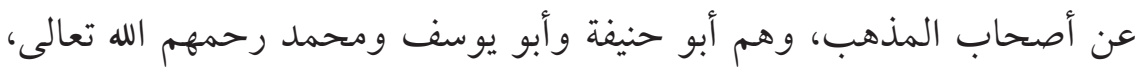

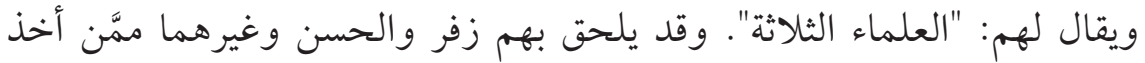

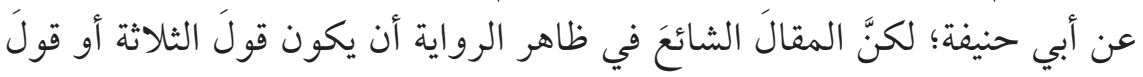
17 بعضئم.

ثم هذه المسائل التي تسمَّى بظاهر الرواية والأصل هي ما وُجد في كتب التب

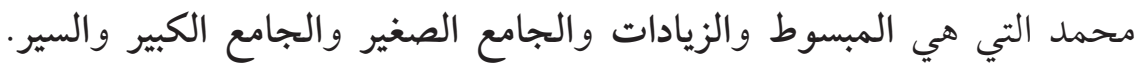

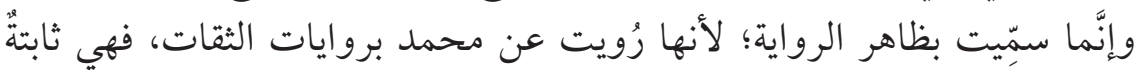

$$
\text { عنه إمَّا متواترةً أو مشهورةً. }
$$

الثانية: "مسائل النو ادر"، وهي VI ' مسائل مروية عن أصحاب المذهب المذكورِينَ؛ لكن لا في الكتب المذكورة؛ بل:

$$
\begin{aligned}
& \text { \& ا ما بين \} \{ من نسخة "ت"، ولا يوجد في سائر نسخ الرسالة. } \\
& 10 \text { ف م + الحنفية. }
\end{aligned}
$$

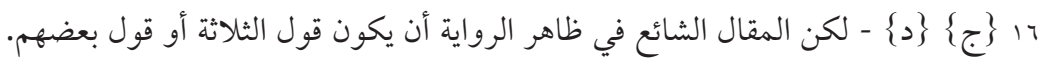
Viv ف الثانية مسائل النوادر وهي. 


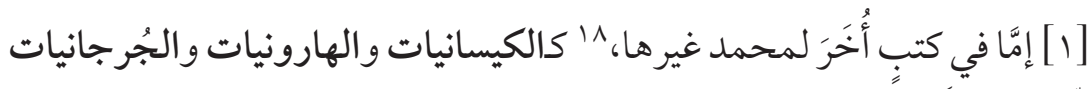

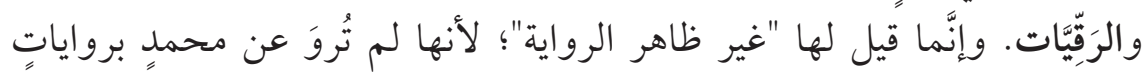
ظاهرةٍ ثابتةٍ صحيحةٍ كالكتب الأولى فئ.

[r] و إمَّا في كتب غيرِ 19 محمد، ككتاب المجرد للحسن بن زياد وغيره.

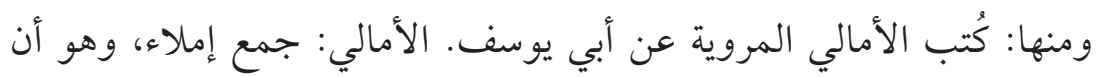

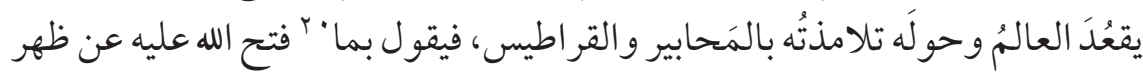

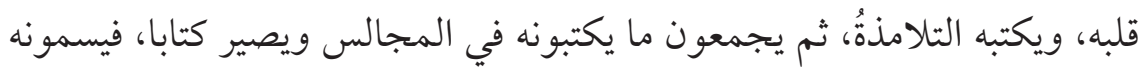

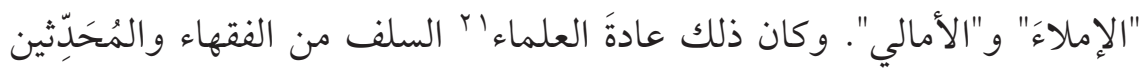

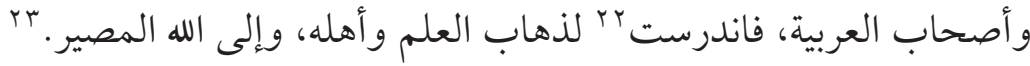
[ب] وإمَّا برواياتٍ مُفَرَدة، مثلَ رواية ابن سماعة، ومعلى بن منصور، وغيرهما في مسائلَ معيَّة. الثالثة: "الفتاوى" وتسمَّى "الواقعات" أيضا، وهي مسائلُ استبطَّها المجتهدون

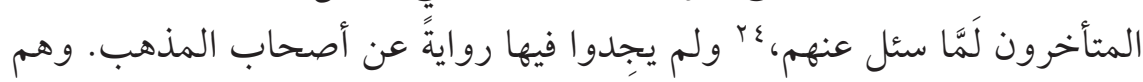

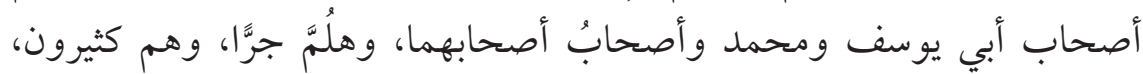
وموضعُ ro ضبطهم كتبُ الطبقات لأصحابنا.

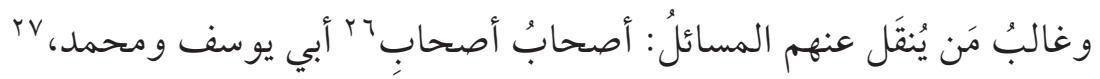

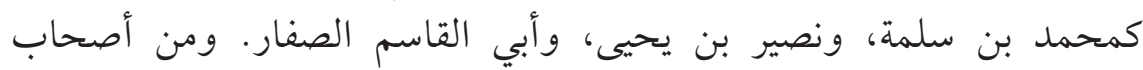

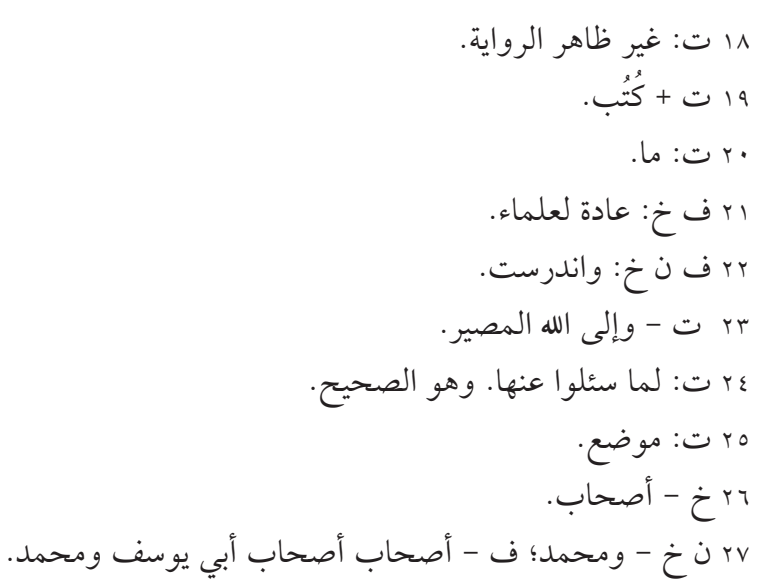




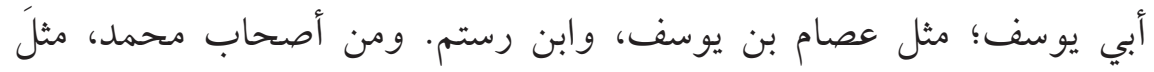

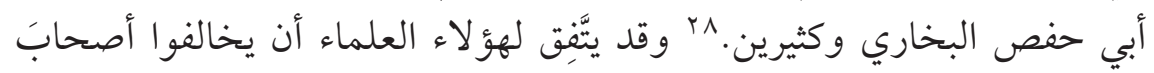

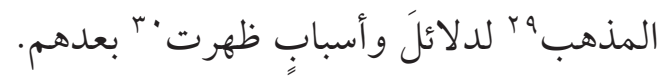

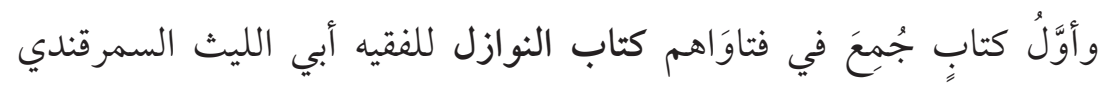

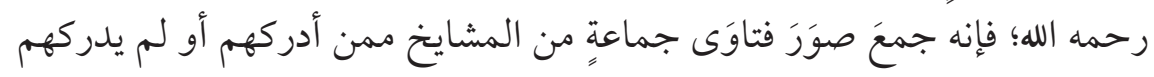

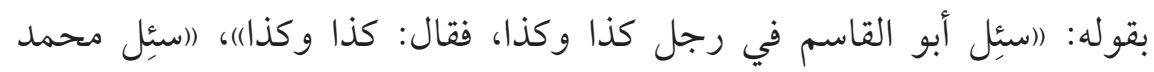

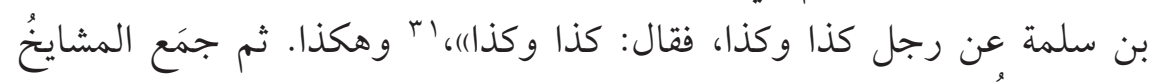

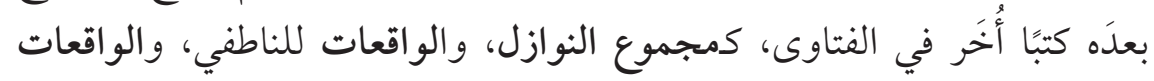

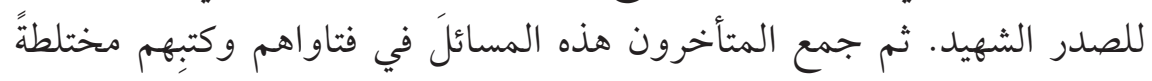

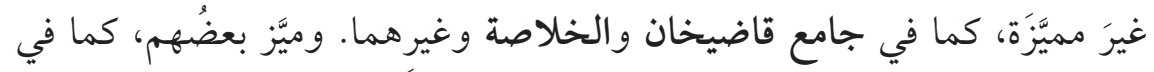

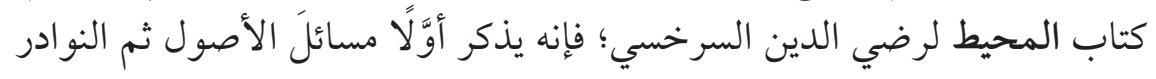

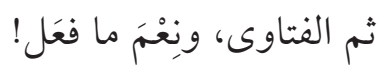

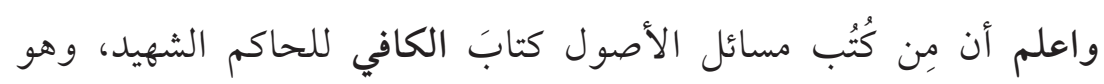

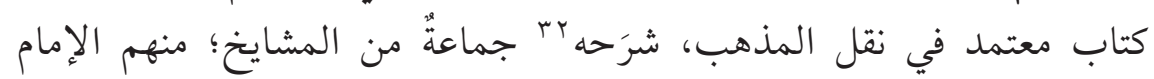

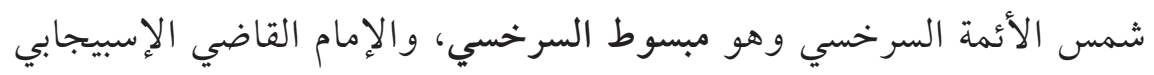

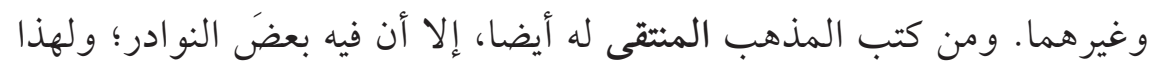

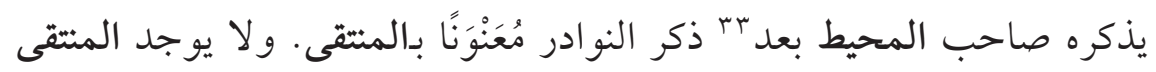
في هذه الأعصار.

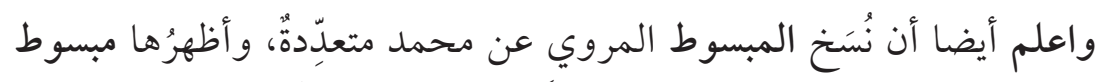

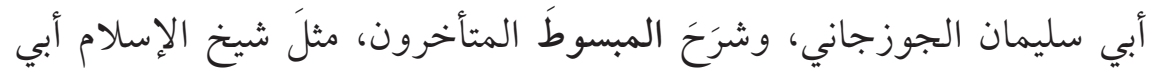

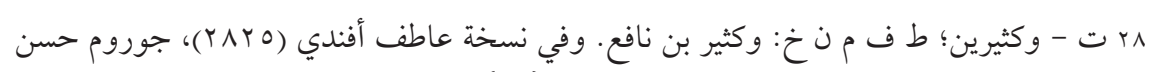

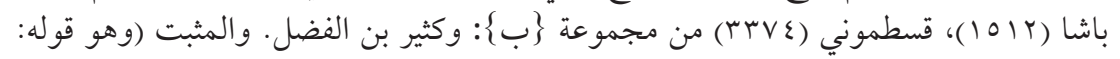

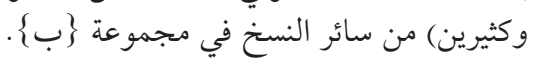

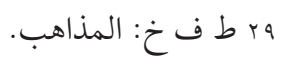

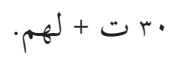

ابr ن - سئل محمد بن سلمة عن رجل كذا و كذا، فقال: كذا وكذا؛ ط - فقال كذا وكذا.

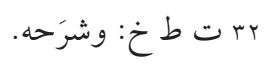

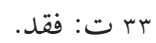




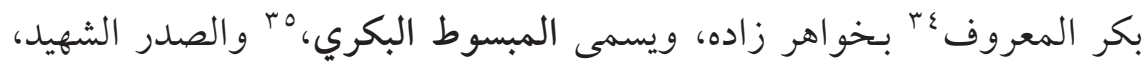

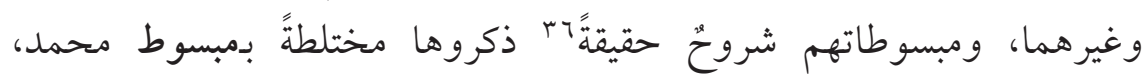

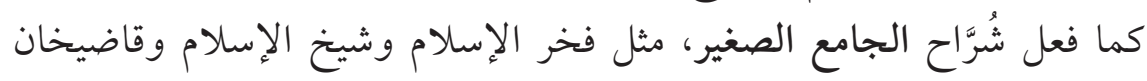

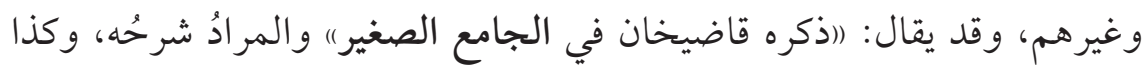

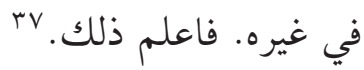

$$
\begin{aligned}
& \text { ع ت ت: مثلَ شيخ الإسلام المسمى. } \\
& \text { هr }
\end{aligned}
$$

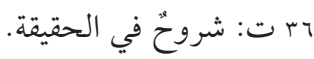

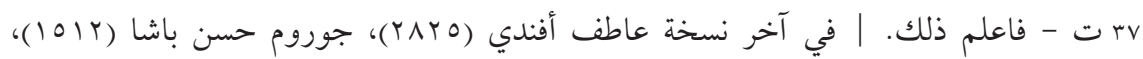

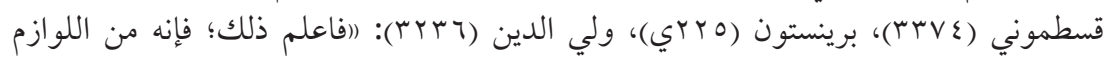

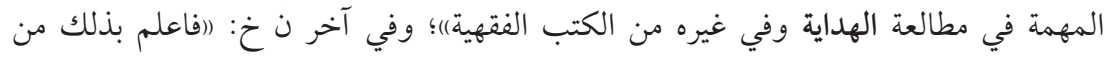

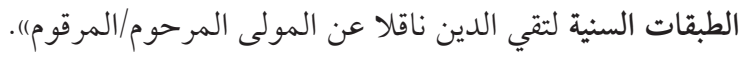




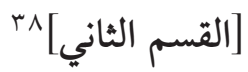

من فوائد علي \لبي المذكور أيضا

\section{مطلب: [فيما نقل عن المشايخ من الفتاوى]}

ما نقل عن مشايخنا في الكتب: إما اجتهادات؛ وإما تخريجات أقوال العلماء

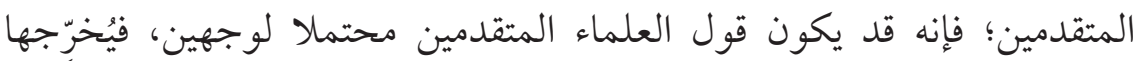

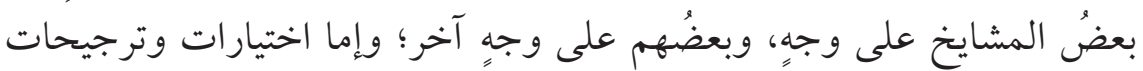

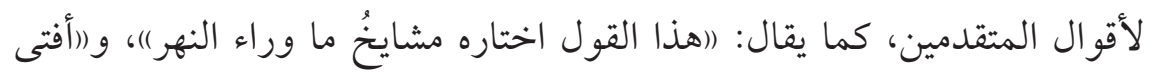

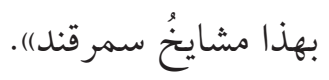

و الغالب على القُدماء منهم الاجتهادُ والتخريجُ، وهم الذين كانوا فيما بين

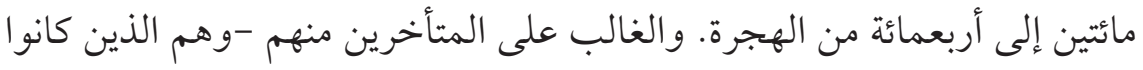

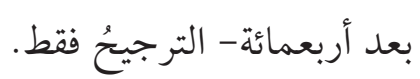

\section{[مطلب: في تأليف كتب المبسوط]}

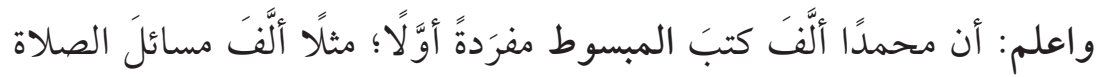
وسماها كتاب الصلاة، ومسائلَ البيوع وسماها كتاب البيوع، وكذا الأيمان

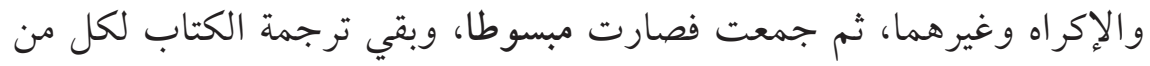

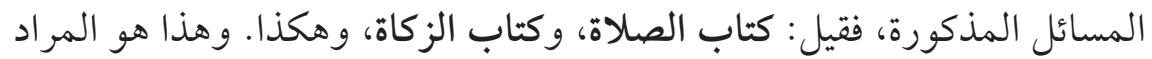

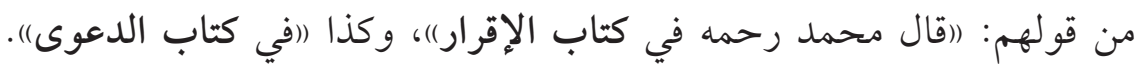
انتهى

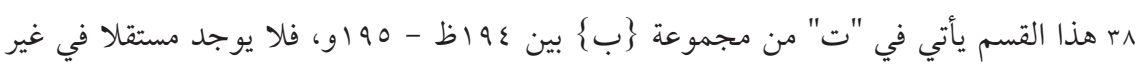

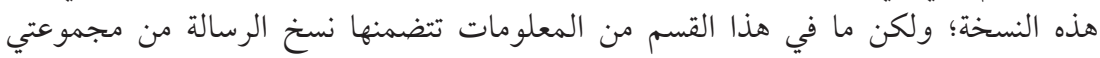

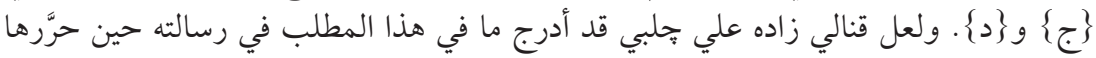

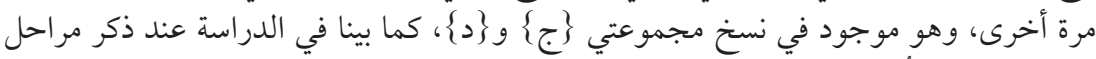

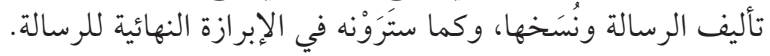




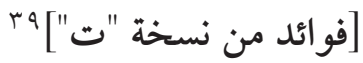

\section{مطلب: [في ظاهر الرواية]}

ثم إذا كانت [المسألة] مذكورة في هذه الكتب: الأصول الأربعة المتقدمة،؛

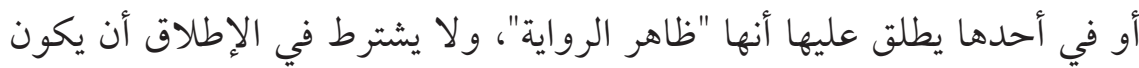

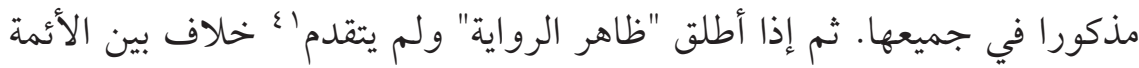

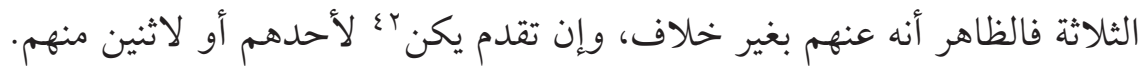
يعرف ذلك بقرينة المقام وسباق الكلام وسياقه.

كذا سُمع من المشايخ، ووجد بخط الشيخ قاسم بن قطلوبغا رحمه الله.

\section{مطلب: [في المراد بظاهر الرواية وغير ظاهر الرواية]}

المراد من "رواية الأصول" وهي "ظاهر الرواية"؛ رواية الجامع الصغير والجامع

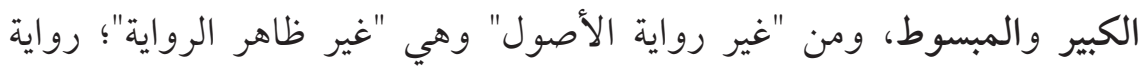

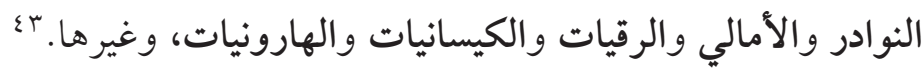

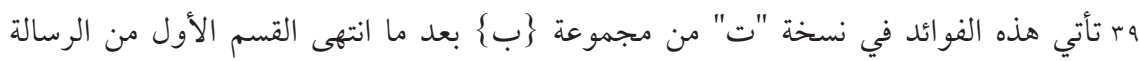

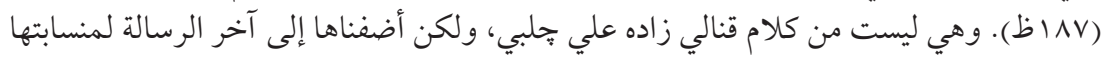

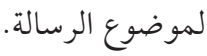

•؛ وهي: المبسوط والجامع الصغير والجامع الكبير والزيادات.

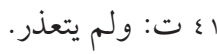

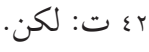

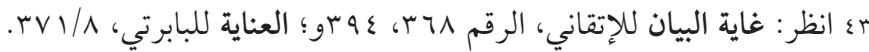




\section{رسالة \\ طبقات المسائل \\ قنالي زاده علي خلبي

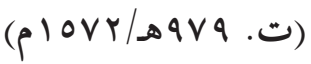

[الإبرازة النهائية للرسالة مستقلةً بعد المزج بين القسمين السابقَين]

$$
\text { بسم الله الرحمن الرحيم }
$$

اعلم -وفَّقك الله- أنَّ مسائلَ أصحابنا الحنفيَّة على ثلاثِ طبقاتٍ:

الأولى: "مسائل الأصول" وتسمَّى "ظاهر الرواية" أيضا، وهي مسائلُ مرويةٌ

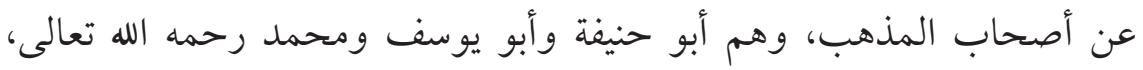

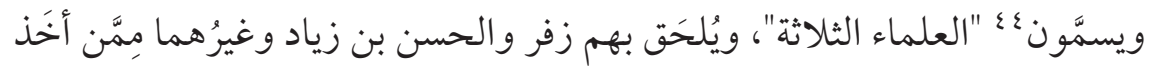

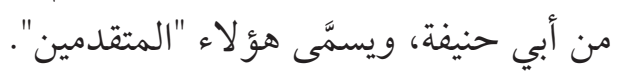

ثم هذه المسائل التي سميت بِ"مسائل الأصل" و "ظاهر الرواية" هي ما وُجِد إِد التِ

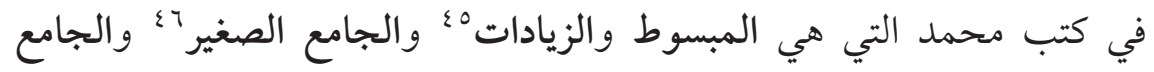

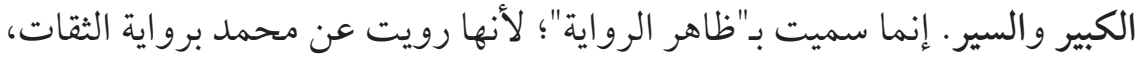

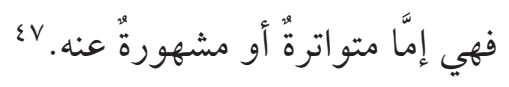

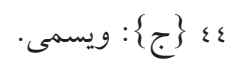

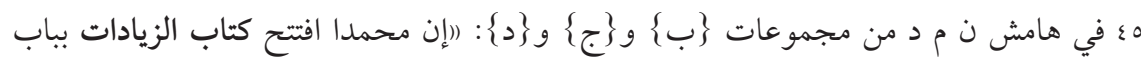

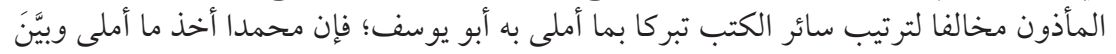

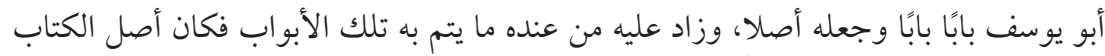

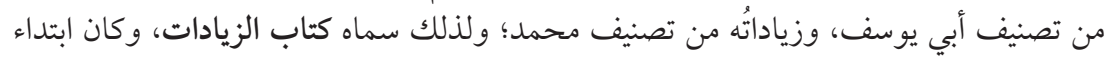

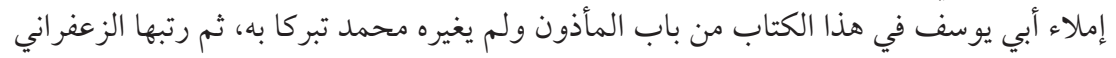

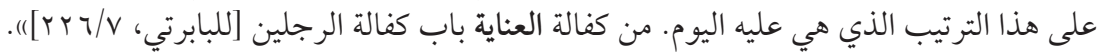

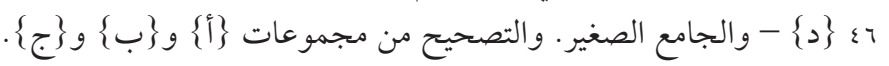

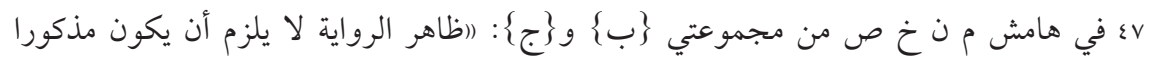

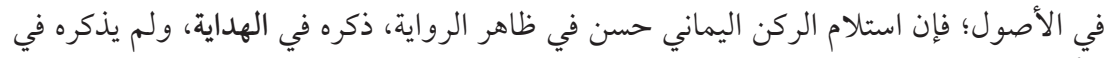

$$
\text { الأصل، ذكره في الذخيرة. كمال باشاز زاده). }
$$


الثانية: "مسائل النو ادر"، وهي مسائلُ مرويَّةٌ عن أصحاب المذهب المذكورِينَ؛

$$
\text { لكن لا في الكتب المذكورة؛ بل: النئ: }
$$

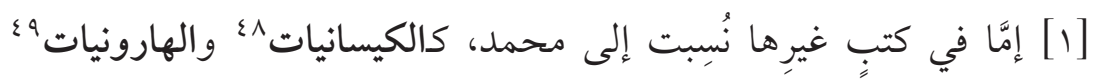
والجرجانيات ·0 والرقيات.

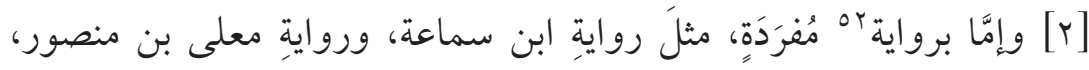
وغيرهما من مسائلَ معيَّنة.

و إنما قيل لها: "غير ظاهر الرواية"؛ لأنها لم تُروَ عن محمد برواياتٍ ظاهرةٍ ثابتةٍ صحيحةٍ كالكتب الأولى.

[r] و إما في كتبِ غيرِ محمد، ككتاب المجرد للحسن بن زياد، وكُتُب الأمالي

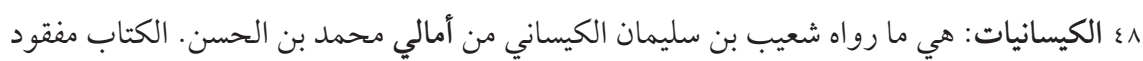

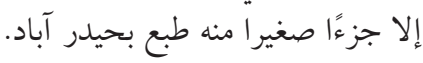

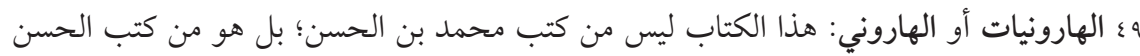

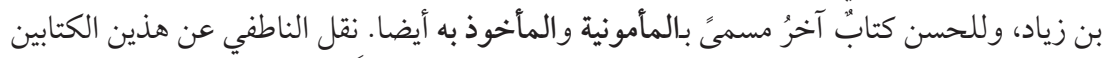

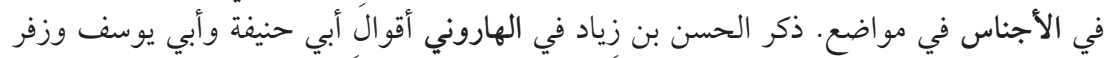

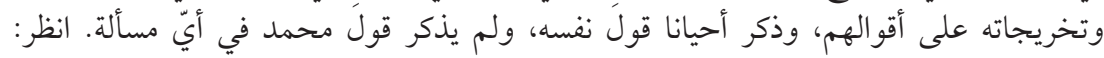

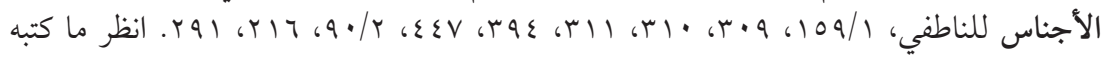

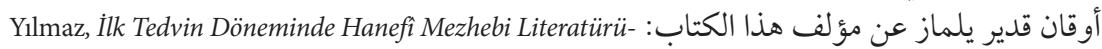

Ençakar, Hanefî Mezhebi Nevâdir Literatürü, s. 94-95: وانظر أيضا: Kayı Eserleri, s. 107-110

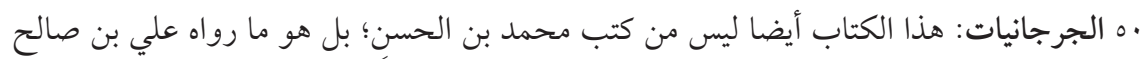

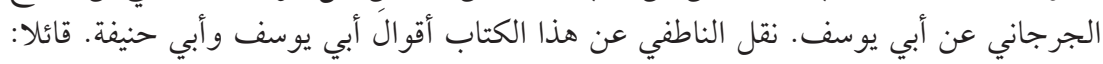

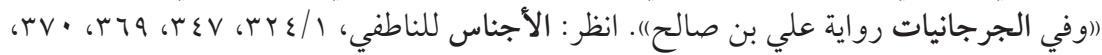

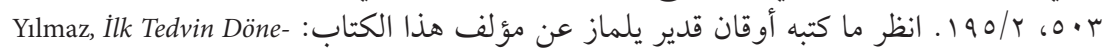
Ençakar, Hanefî Mezhebi minde Hanefî Mezhebi Literatürünün Kayıp Eserleri, s. 110

Nevâdir Literatürü, s. 95-96.

اه الرقيات: اسمُ كتاب أملاه محمد بالرقة حين كان قاضيا بها. انظر: غمز عيون البصائر للحموي،

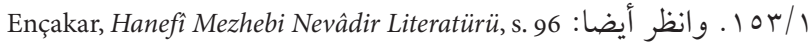
(

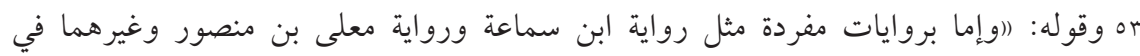

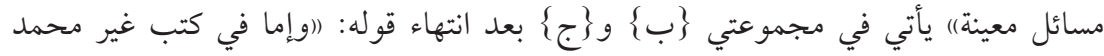

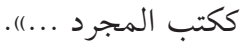




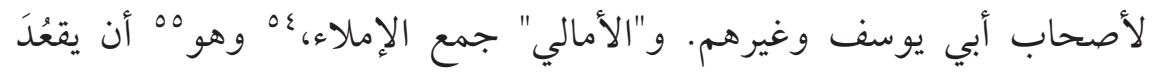

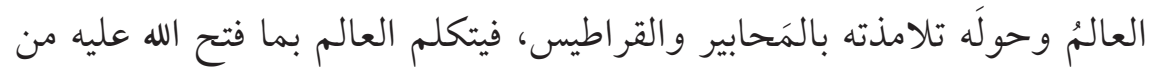

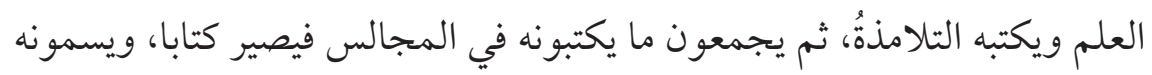

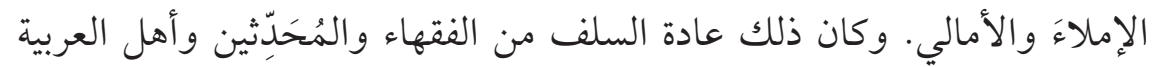

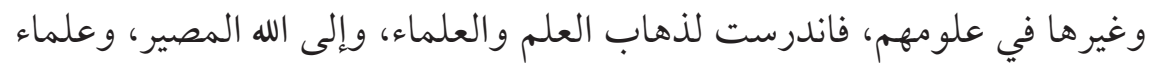
الشافعية يسمون مثله "التعليقة".

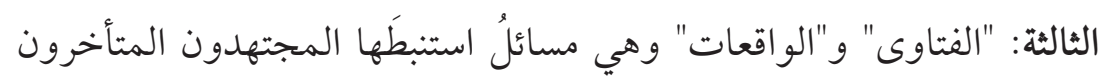

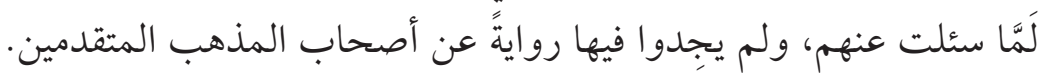

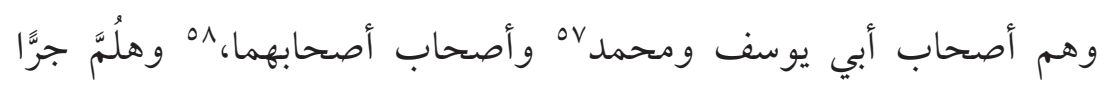

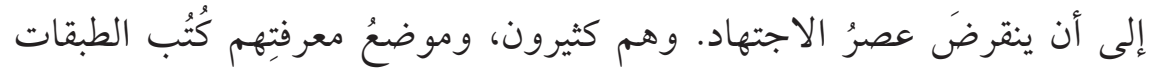
لأصحابنا، وكُتُب التواريخ.

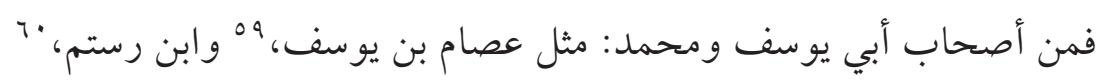

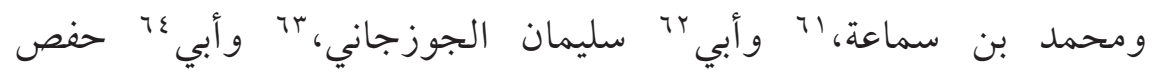

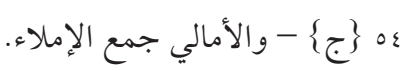

$$
\begin{aligned}
& \text { مه } \\
& \text { ro ب: التعليقية. } \\
& \text { ov ov } \\
& \text { ه ب ب: وأصحاب أبي يوسف. }
\end{aligned}
$$

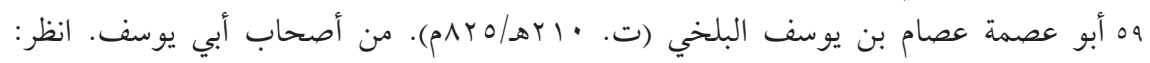

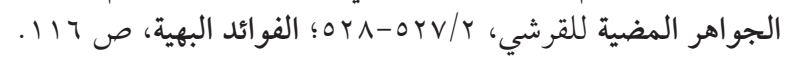

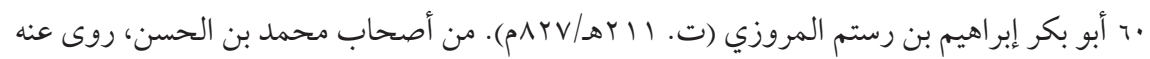

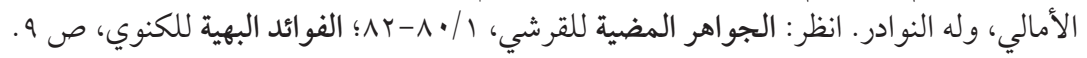

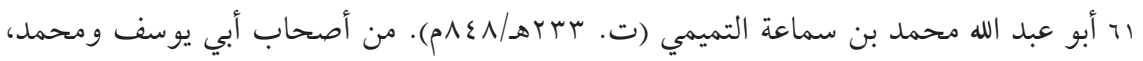

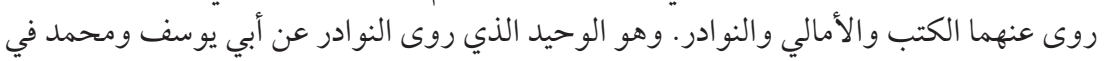

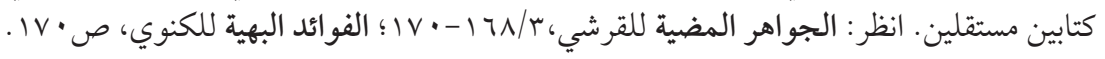

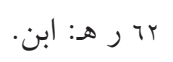

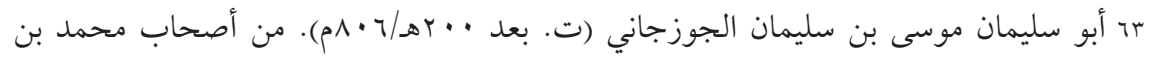

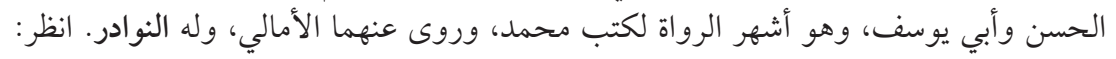

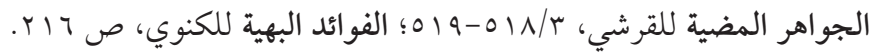

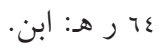


البخاري، 70 وغيرِهم. ومن أصحاب أصحابهما ومَن بعدَهم: مثل محمد

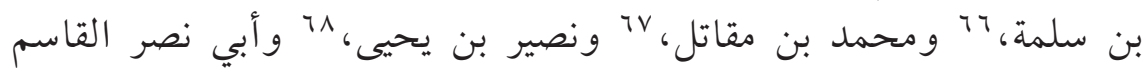

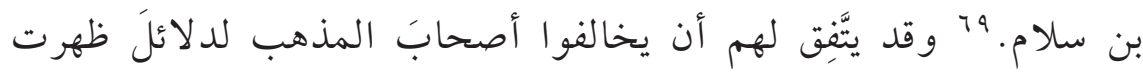

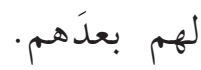

وأوَّلُ كتابٍ جُمعَع في فتاوَاهم فيما بلغنا كتاب النوازل للفقيه أبي الليث

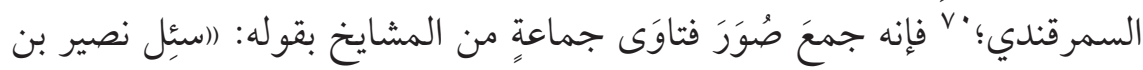

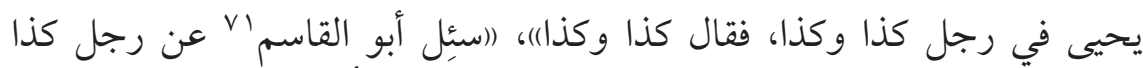

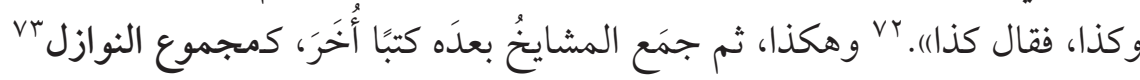

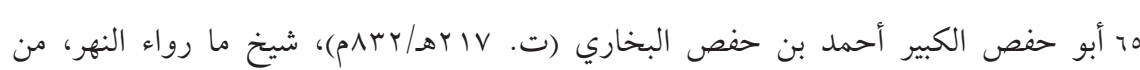

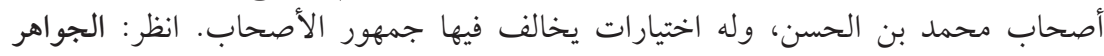

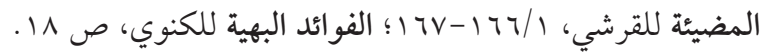

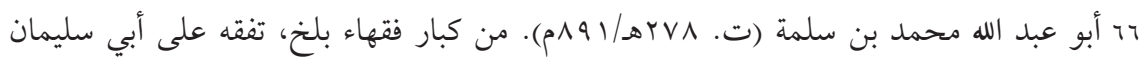

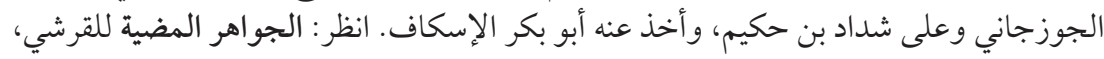

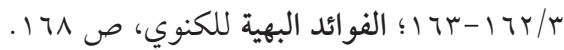

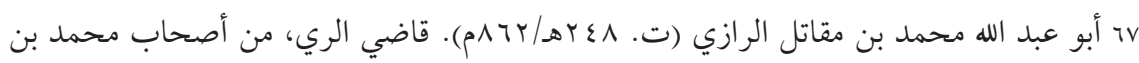

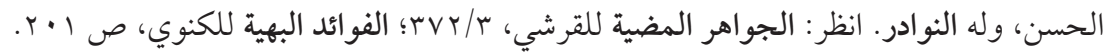

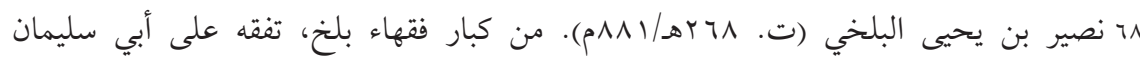

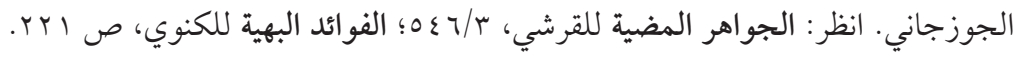

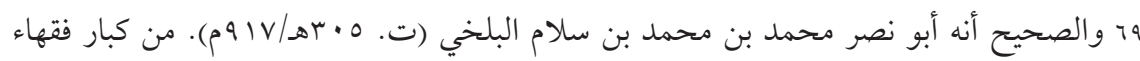

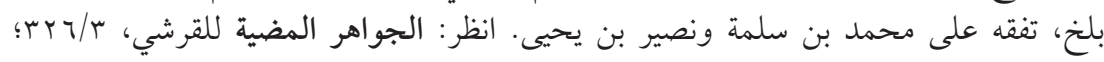

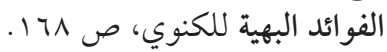

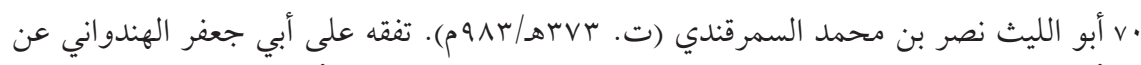

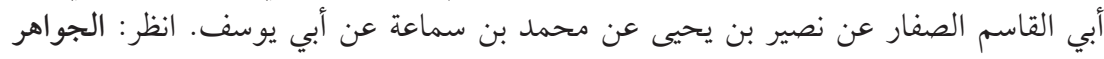

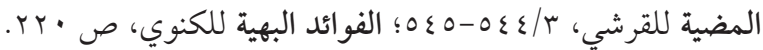

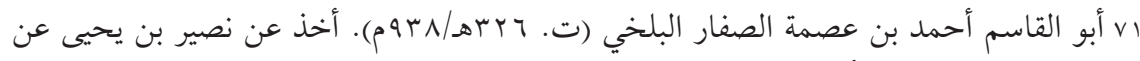

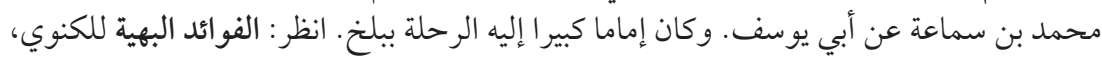

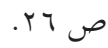

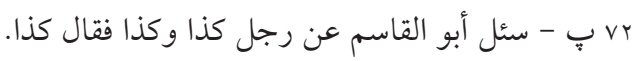

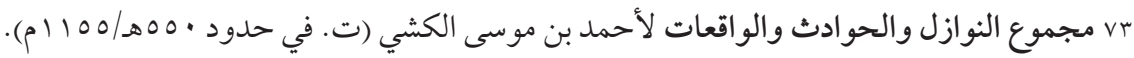

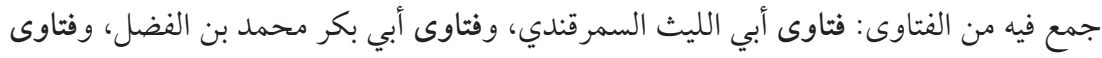

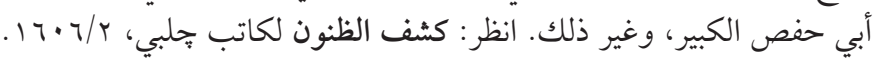




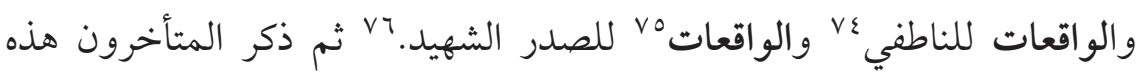

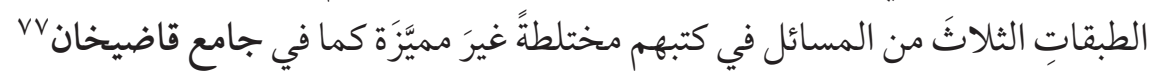

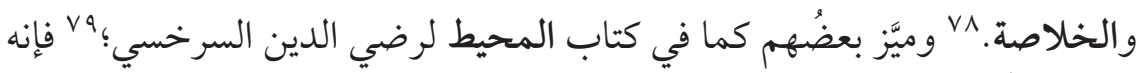

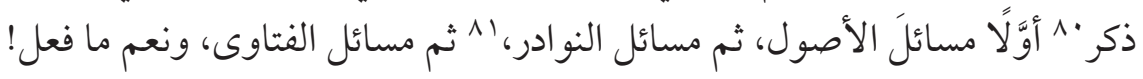
فحيثما يُطلقَ في كتبناب^ "المشايخُ المتأخِرون" فالمراد: ما ذكرنا. وما نقل

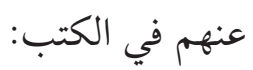
[1] [إما الاجتهادات كما نقلنا. [r] و إما تخريجات أقوال العلماء المتقدمين؛ فإنه قد يكون قول المتقدمين

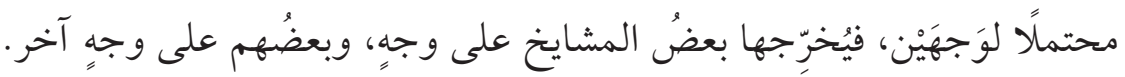

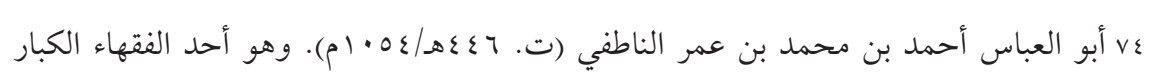

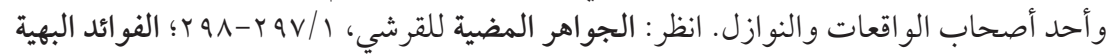

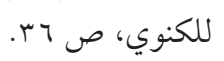

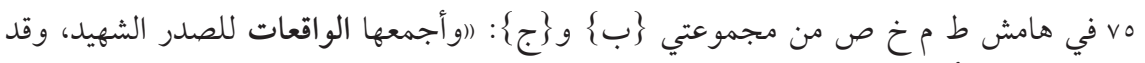

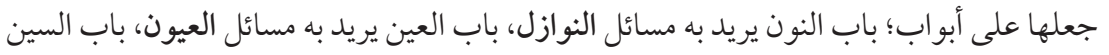

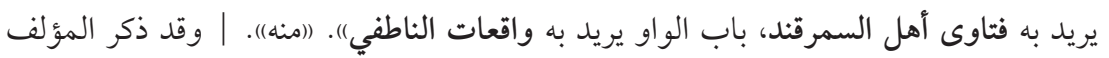

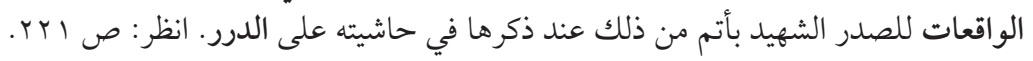

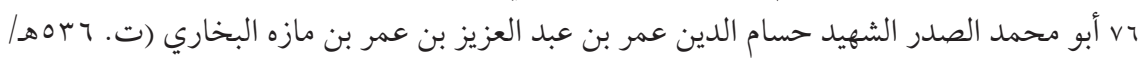

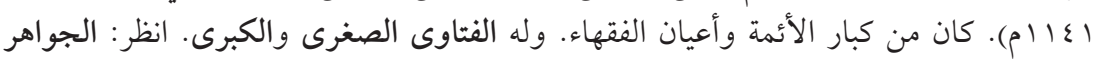

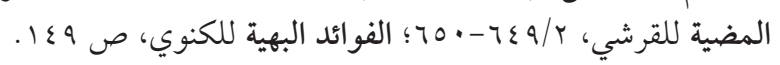

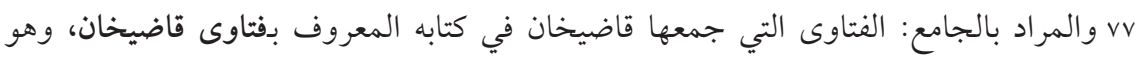

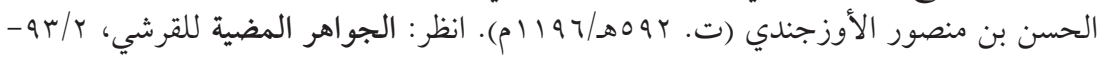

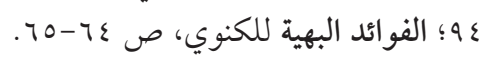

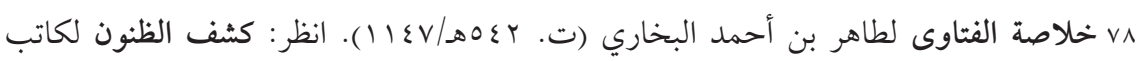

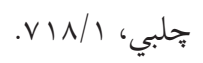

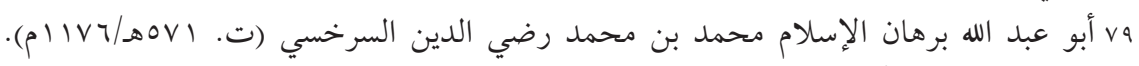

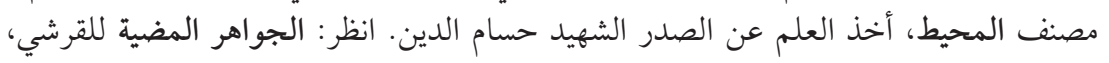
r r rov/r

$$
\begin{aligned}
& \text { • }
\end{aligned}
$$

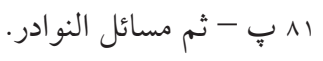

$$
\begin{aligned}
& \text { بr }
\end{aligned}
$$




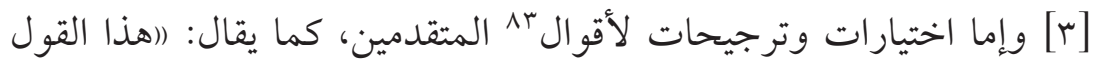

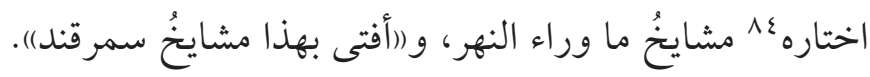

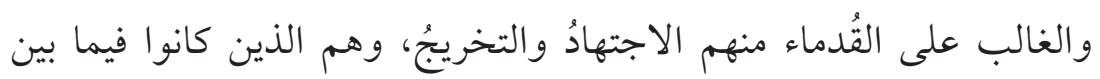

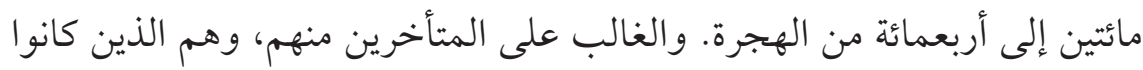
بعد أربعمائة: الترجيحُ. 10

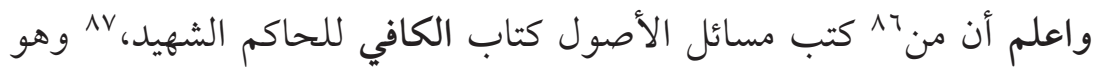

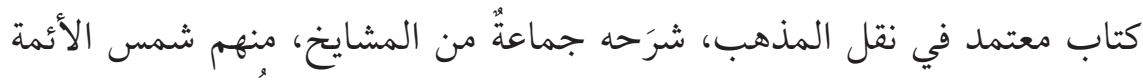

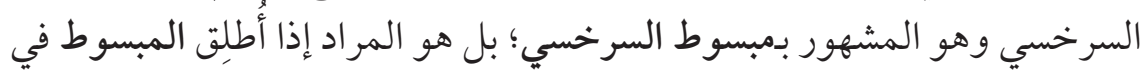

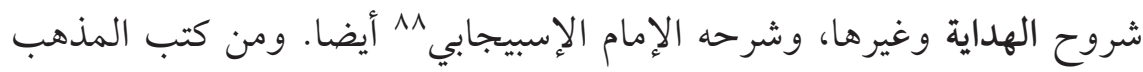

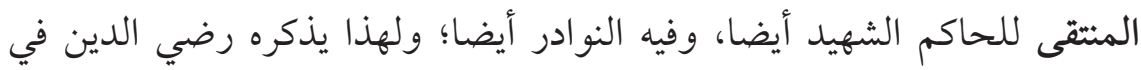
المحيط بعد نقل النوادر، ولا يوجد المتتقى في هذه الأعصار.

واعلم أن نسخ المبسوط المروية عن محمد متعددة، وأظهرها مبسوط أبي

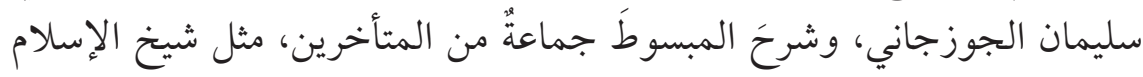

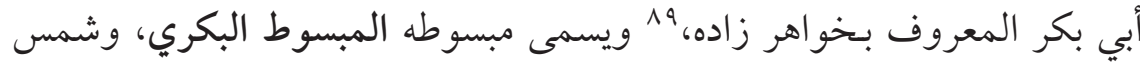

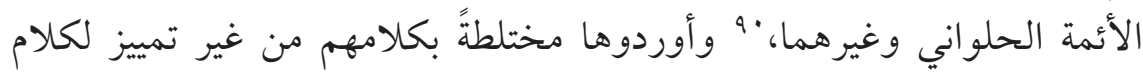

$$
\begin{aligned}
& \text { ع^ }
\end{aligned}
$$

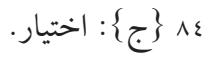

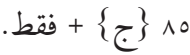

$$
\begin{aligned}
& \text { }
\end{aligned}
$$

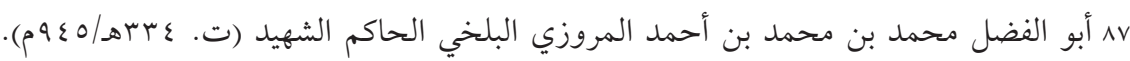

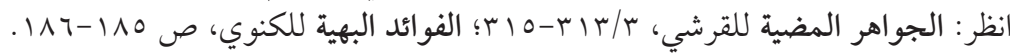

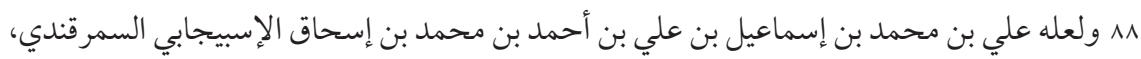

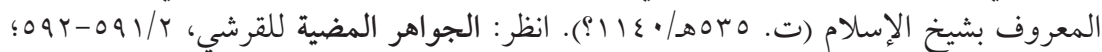

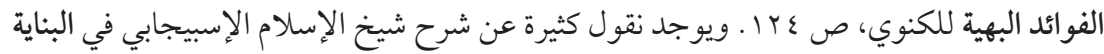

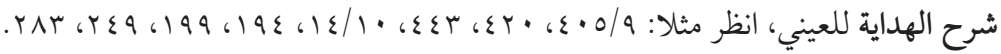

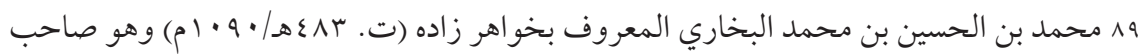

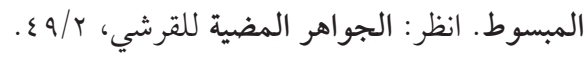

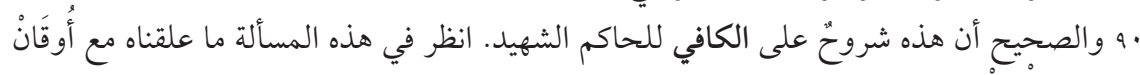

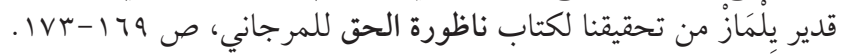




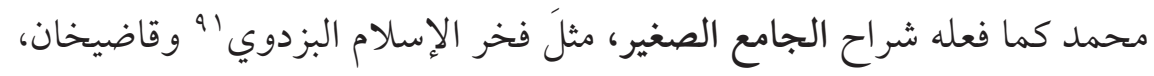

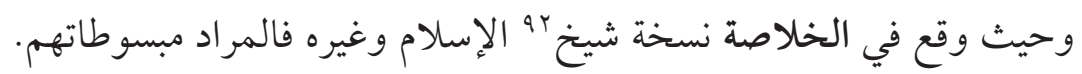

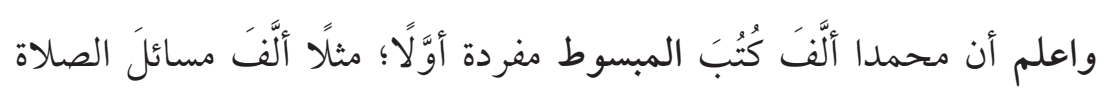

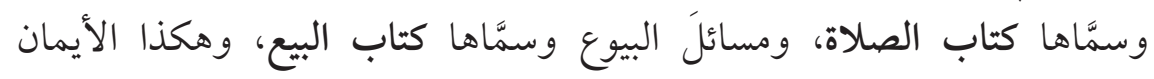

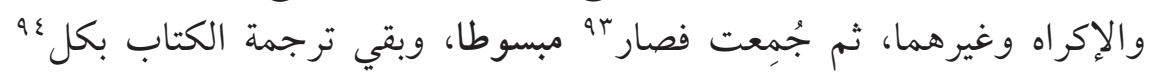

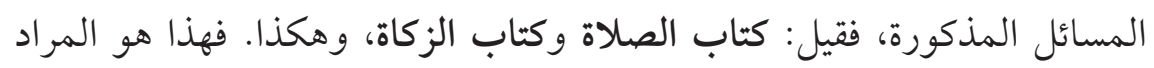
حيث وقع في الكتب: ((قال محمد في كتاب الإقرار))، وكذا ((في كتاب الدعوى)). [تمت الرسالة]

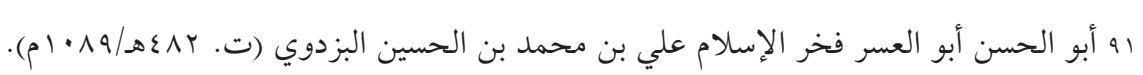

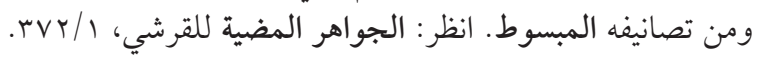

$$
\begin{aligned}
& \text { ه } \\
& \text { r r } \\
& \text { ع }\} \text { צج: }
\end{aligned}
$$




\section{[فوائد من نسختي "ن" و"ص"]}

[مطلب: في ظاهر الرواية وغير ظاهر الرواية]90]

المراد بالأصول: المبسوط والجامعان والزيادات، ومن غير الأصول: النوادر

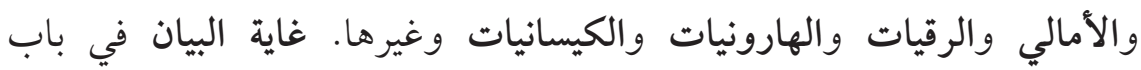

و المر اد بالأصول: الجامعان والزيادات والمبسوط ويعبر عنها بـ"ظاهر الرواية"، وعن الأمالي والنوادر والرقيات والهارونيات والكيات الكيسانيات بـ"غير ظاهر الرواية".

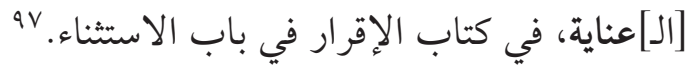
ولم يعدً السير في الأولى ^91 والجرجانيات في الثانية.99 [مطلب: في أن كل ما يوجد في الأصول ليس بظاهر الرواية]..' أقول: الظاهر من العناية أن يكون كل ما يوجد في الأصول ظاهر الرواية، لكن من تتبع كلمات المشايخ يحكم بخلافه.

منها: ما ذكر في فتاوى قاضيخان (أن في منكر الأيام ’” عن أبي حنيفة روايتين:

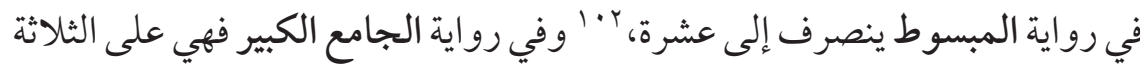

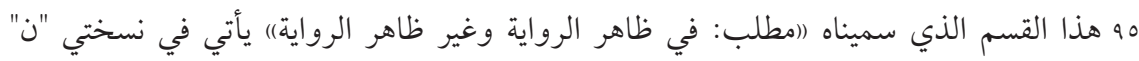

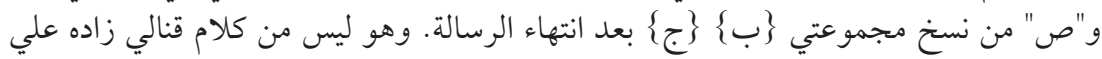

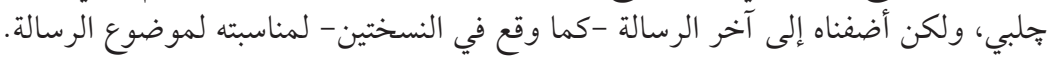

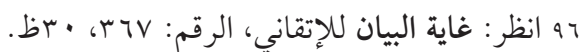

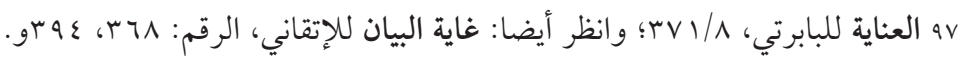

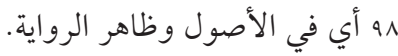

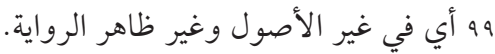
.... هذا القسم الذي سميناه (امطلب: في أن كل ما ما يوجد في الأصول ليس بظاهر الرواية) يأتي أيضا في نسخة "ن" من مجموعة (ب) النئ بعد انتهاء الرسالة.

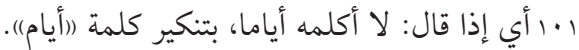

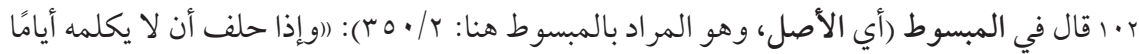

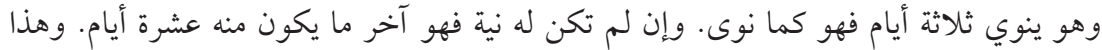

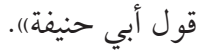




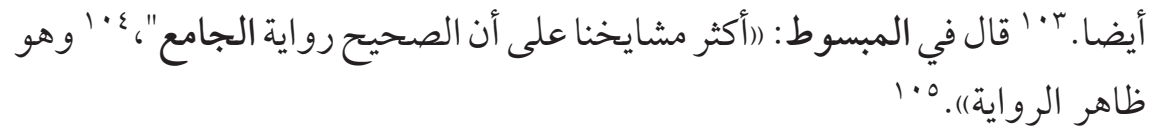
ومنها: ما ذكر في البدائع: (اوأما آخر الظهر فلم يذكر في ظاهر الرواية أيضا،

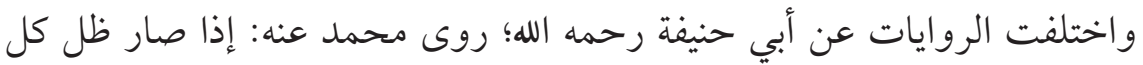

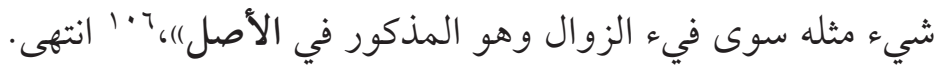
ومنها: ما في بعض الكتب المعتبرة: ذكر الحاكم الشهيد في المنتقى: ثم يشترط العصر ثلاث مرات في ظاهر رواية الأصل، انتهى. فهذا يدل على أن كل ما يذكر في المبسوط ليس بظاهر الرواية.

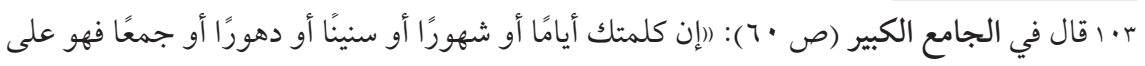

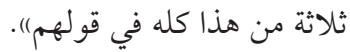

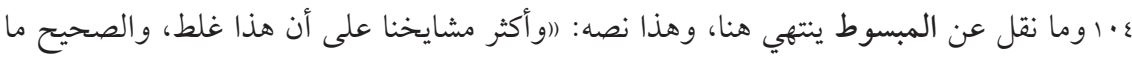

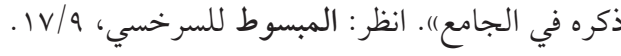

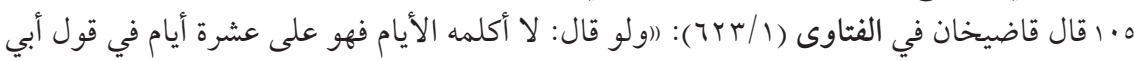

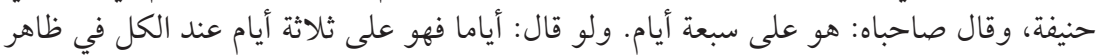

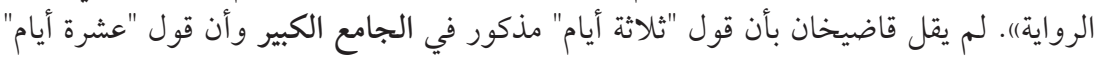

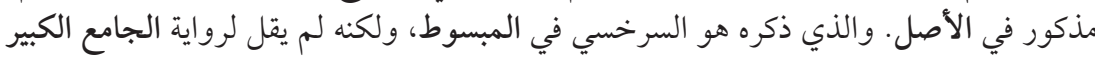

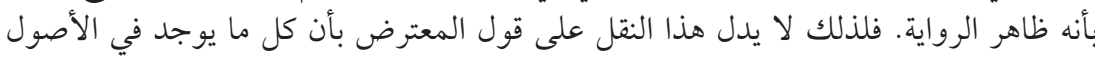

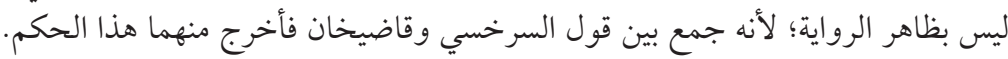

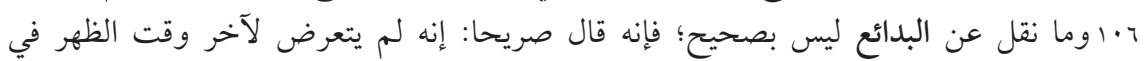

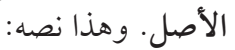

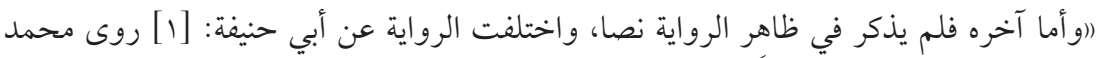

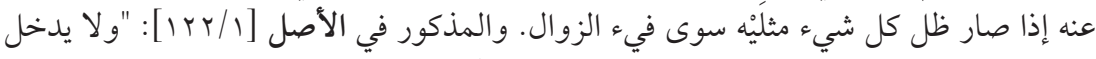

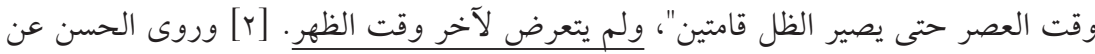

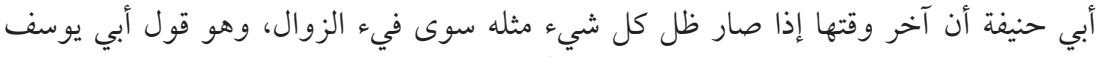

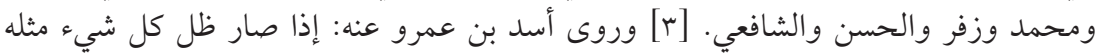

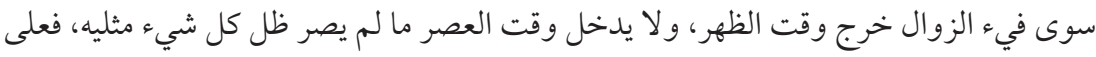

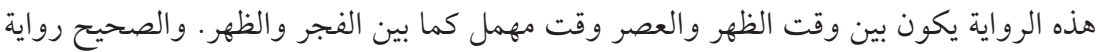

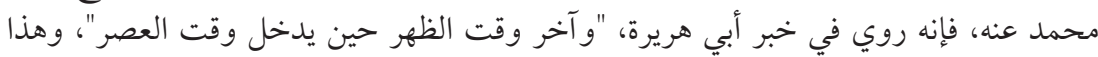

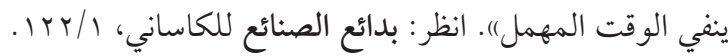

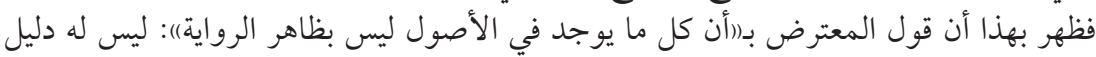
فيما نقله عن فتاوى قاضيخان والمبسوط والبد لمنائع. 


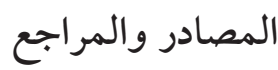

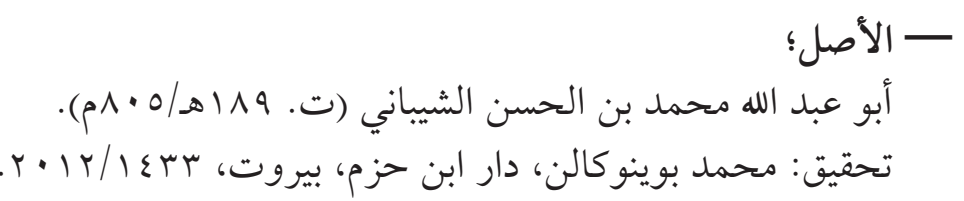

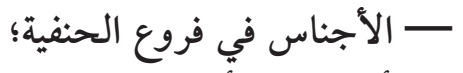

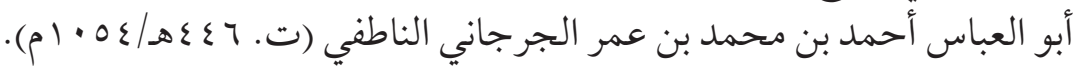

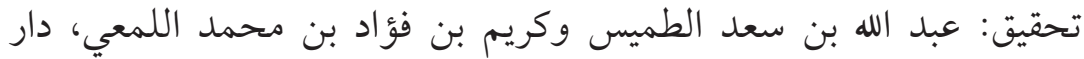

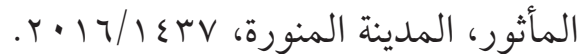

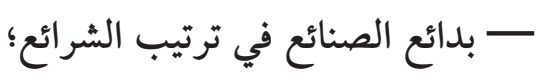

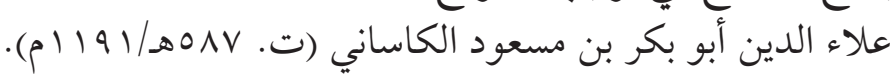

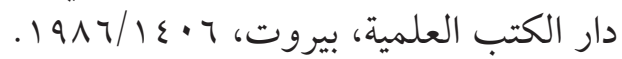
- البناية في شرح الهداية؛

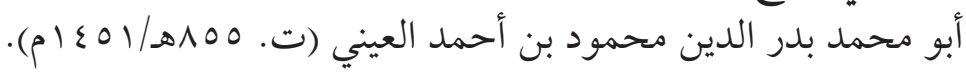

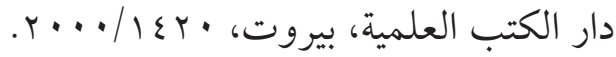
- الجواهر المضية في طبقات الحنفية؛

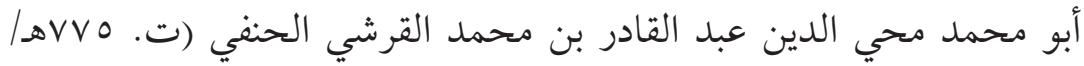

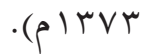

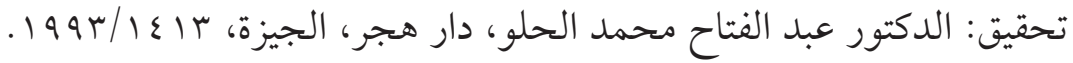
- العناية شرح الهداية؛

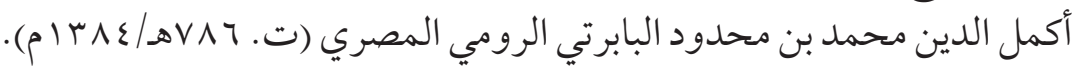

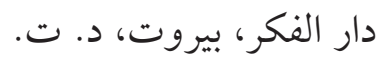

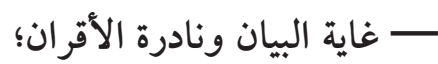

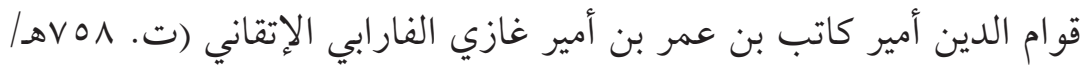
. p p rov

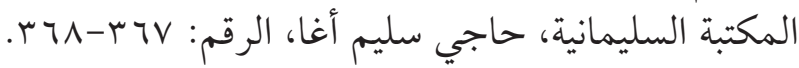

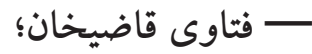
أبو المحاسن فخر الدين الحسن بن منصور الأوزجندي الفرغاني (ت. به هـهـ (p) 197 نشر: سالم مصطفى البدوي، دار الكتب العلمية، بيروت، 9 × ·. 


$$
\text { - الفوائد البهية في تراجم الحنفية؛ }
$$

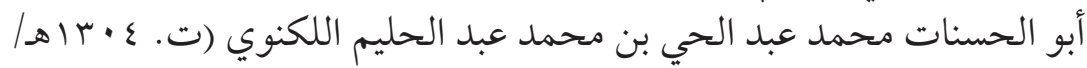

$$
\text { دار المعرفة، الم) بيروت، د. }
$$

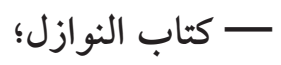

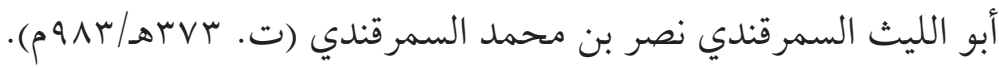

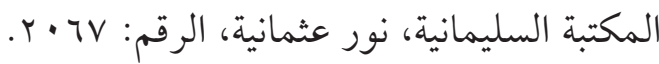

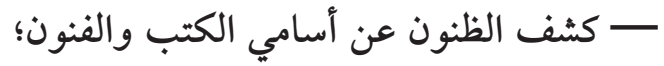

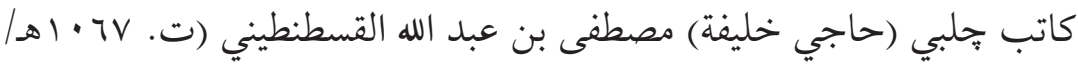

(م) ن (م)

نشر: شراف الدين يالتقايا ورفعت بيلكه الكليسي، دار إحياء التراث العربي،

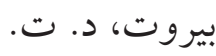

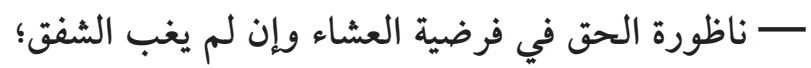

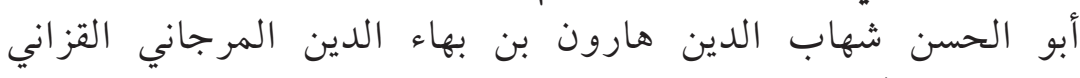

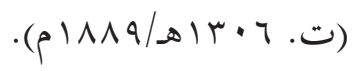

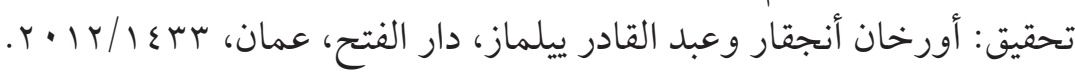

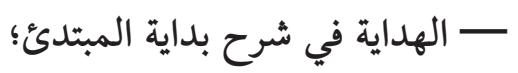

أبو الحسن برهان الدين علي بن أبي بكر بن عبد الجليل الفرائ الفبن غاني المرغيناني

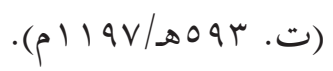

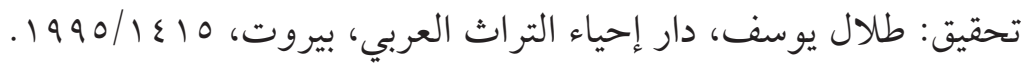

$$
\text { المصادر غير العربية }
$$

Ençakar, Orhan, Hanefî Mezhebi Nevâdir Literatürü (doktora tezi), Marmara Üniversitesi Sosyal Bilimler Enstitüsü, 2019.

Yllmaz, Okan Kadir, İlk Tedvin Döneminde Hanefî Mezhebi Literatürünün Kayıp Eserleri (yüksek lisans tezi), Marmara Üniversitesi Sosyal Bilimler Enstitüsü, 2017. 


\section{Bibliyografya}

Aynî, Bedreddin, el-Binâye şerhu’l-Hidâye, nşr. Eymen Sâlih Şa 'bân, I-XIII, Beyrut: Dârü'lkütübil'-ilmiyye, 1420/2000.

Bâbertî, el-İnâye şerhu'l-Hidâye, Beyrut: Dârü'l-fikr, t.y.

Bedir, Mürteza, Buhara Hukuk Okulu, İstanbul: İSAM Yayınları, 2014.

Boynukalın, Mehmet, el-Asl: Mukaddime, Beyrut: Dâru İbn Hazm, 1433/2012.

Cürcânî, Seyyid Şerîf, et-Ta'rîfât, nşr. Muhammed Bâsil Uyûnü’s-Sûd, Beyrut: Dârü'lkütübi'l-ilmiyye 1424/2003.

Ençakar, Orhan, Hanefî Mezhebi Nevâdir Literatürü (doktora tezi), Marmara Üniversitesi, İstanbul, 2019.

Ençakar, Orhan, “Bir Mezhebin Yitik Kültürü: Hanefî Mezhebi Nevâdir Literatürü”, İslam Araştırmaları Dergisi, 44 (2020): 1-36.

Furat, Ahmet Hamdi, Muallâ b. Mansûr'un Nevâdir'i ve Hanefi Mezhebi Literatüründeki Yeri, İstanbul: Reha Yayınları, 2013.

Hamevî, Ahmed b. Muhammed, İthâfüll-ahbâb bi-beyâni tabakāti mesâili kütübill-ashâb, Süleymaniye Ktp., Laleli, nr. 3706.

Hâkim eş-Şehîd, el-Kâfî, Süleymaniye Ktp., Hamidiye, nr. 545; Şehid Ali Paşa, nr. 912.

İbn Âbidîn, Muhammed Emîn, Şerhu Ukūdi resmill-müftî, Resâilü İbn Âbidîn içinde, I-II, y.y.: Dâru ihyâi't-türâsi'l-Arabî, t.y.

İbn Ebü’l-Avvâm, Abdullah b. Muhammed, Fezâilü Ebî Hanîfe ve ahbârühû ve menâkıbüh, nşr. Latîfürrahman el-Behrâicî, Mekke: el-Mektebetü'l-imdâdiyye, 1431/2010.

İtkānî, Gāyetüll-beyân ve nâdiretüll-akrân, Süleymaniye Ktp., Hacı Selim Ağa, nr. 367-368.

Kādîhân, el-Fetâvâ, nşr. Sâlim Mustafa el-Bedevî, I-III, Beyrut: Dârü'l-kütübi'l-ilmiyye, 1430/2009.

Kâsânî, Bedâiu’s-sanâi‘, I-VII, Beyrut: Dârü'l-kütübi'l-ilmiyye, 1406/1986.

Kâtib Çelebi, Keşfü̉z-zunûn, nşr. M. Şerefeddin Yaltkaya - Kilisli Rifat Bilge, I-II, Beyrut: Dâru ihyâi't-türâsi'l-Arabî, t.y.

Kefevî, Mahmûd b. Süleyman, Ketâibü a'lâmi'l-ahyâr min fukahâi mezhebi'n-Nu'mâni'lmuhtâr, nşr. Saffet Köse v.dğr., I-IV, İstanbul: Mektebetü’l-irşâd, 1438/2017.

Kınalızâde Ali Efendi, Hâş̧iye ale'l-Dürer, Süleymaniye Ktp., Şehid Ali Paşa, nr. 749; Yenicami, nr. 397; Kasîdecizâde Süleyman Sırrı, nr. 2454.

Kınalızâde Ali Efendi, Risâle fî tabakāti’l-mesâil, Diyanet İşleri Başkanlığı Ktp., nr. 1212.

Kudûrî, Şerhu Muhtasari'l-Kerhî, Köprülü Ktp., Hâfız Ahmed Paşa, nr. 93.

Kureşî, el-Cevâhirü̉l-mudiyye, nşr. Abdülfettâh Muhammed el-Hulv, I-V, Kahire: Hecer li’t-tıbâa ve'n-neşr, 1413/1993.

Leknevî, en-Nâfiu'l-kebîr limen yutâliu'l-Câmia's-sagìr, Karaçi: İdâretü'l-Kur'an ve'l-ulûmi'l-İslâmiyye, 1411/ 1990.

Leknevî, el-Fevâidüll-behiyye, Beyrut: Dârü'l-ma'rife, t.y.

Leknevî, Umdetürr-riâye alâşserhi'l-Vikāye, nşr. Salâh Muhammed Ebü’l-Hâc, I-VII, Beyrut: Dârü'l-kütübi'l-ilmiyye, 2009. 
Mercânî, Nâzûratüll-hak fî farziyyetill-işâ ve in lem yeğibiş̧-şafak, nşr. Orhan Ençakar Abdülkadir Yılmaz, Amman: Dârü'l-feth, 1433/2012.

Mergīnânî, Burhâneddin, el-Hidâye, nşr. Tilâl Yûsuf, I-II, Beyrut: Dâru ihyâi't-türâsi'lArabî, 1415/1995.

Nablusî, İsmâil b. Abdülganî, el-İhkâm fî şerhi Düreril-hükkâm, Dârü’l-kütübi'z-Zâhiriyye, nr. 5184.

Orazov, Orazsahet, "Hanefi Fıkıh Edebiyatının Tasnifi: Kınalızâde Ali Çelebi’nin Risâle fî beyâni'l-1stılâhâti'l-mütedâvilât fî̀ kütübi'l-fikh Adlı Risalesinin Tahlili, Tahkiki ve Çevirisi”, İslam Hukuku Araştırmaları Dergisi, 37 (2021): 365-396.

Pîrîzâde İbrâhîm, Umdetü zevi'l-basâir li-halli mübhemâti'l-Eşbâh ve’n-nezâir, Mektebetü Câmiati'r Riyâd, nr. 1820.

Saymerî, Hüseyin b. Ali, Ahbâru Ebî Hanîfe ve ashâbih, Beyrut: Âlemül-kütüb, 1405/1985.

Semerkandî, Ebü'l-Leys, Kitâbün-Nevâzil, Nuruosmaniye Ktp., nr. 2067.

Serahsî, Șemsüleimme, el-Mebsût, I-XXX, Beyrut: Dârü'l-ma'rife, 1409/1989.

Şeybânî, Muhammed b. Hasan, el-Asl, nşr. Mehmet Boynukalın, I-XII, Beyrut: Dâru İbn Hazm, 1433/2012.

Şeybânî, Muhammed b. Hasan, Cüz' mine’l-emâlî, nşr. Hâşim en-Nedvî v.dğr., Haydarâbâd: Matbaatü Dâireti'l-maârifi'l-Osmâniyye, 1407/1986.

Taşköprizâde Ahmed Efendi, Miftâhu’s-saâde, I-III, Beyrut: Dârü'l-kütübi'l-ilmiyye, 1405/1985.

Temîmî, Takıyyüddin b. Abdülkādir, et-Tabakātü̉s-seniyye fî̀ terâcimìl-Hanefiyye, nşr. Abdülfettâh Muhammed el-Hulv, I-IV, Kahire: Lecnetü ihyâi't-türâsi'l-İslâmî, 1390/1970.

Yılmaz, Okan Kadir, İlk Tedvin Döneminde Hanefì Mezhebi Literatürünün Kayıp Eserleri (yüksek lisans tezi), Marmara Üniversitesi, İstanbul, 2017.

\section{A Critical Edition and Analysis of Kınalızade Ali Efendi’s (d. 979/1572) Tabaqāt al-masā'il}

Ṭabaqāt al-masā'il, authored by Ottoman scholar Kınalızade Ali Efendi, is the first independent treatise on the characteristics and sources of the concepts zāhir al-riwāya and ghayr zāhir al-riwāya. These concepts are used to classify legal responsa of the Hanafi school of law transmitted from the school's preeminent scholars in respect to their epistemological and referential value. Kınalızade brought together issues discussed in the school under three headings by adding fatāwa- the opinions of jurists who came after Abū Hanīfa and his students-alongside these two categories. He defined each category and provided examples. His definitions and categorizations of the concepts, particularly ușūl and nawādir, influenced the following literature and these two concepts came to be understood according to Kinalızde's definitions. Zāhir al-riwāya appeared as an umbrella concept comprising ușūl and jawāmic in the legal questions tackled by the Hanafi school. By redefining uṣūl-a concept categorized under the heading of zähir al-riwāya in the early period, firstly 
by Itqānī (d. 758/1357) and through his influence on certain Hanafi jurists like Bābartī (d. 786/1384), Badr al-Dīn al-'Aynī (d. 855/1451), and Qāsim b. Quṭlūbughā (d. 879/1474) - ușūl and zāhir al-riwāya came to be used interchangeably. Following the same path, Kinalizade wrote an independent treatise on the subject, which led the new definition to circulate in Hanafi circles and opened a path for later scholarship to develop around the new definitions adopted in this treatise.

Just like the synonymous usage of $u s ̣ \bar{u} l$ and $z \bar{a} h i r$ al-riwāya, Kınalızade defined the concepts of ghayr zāhir al-riwāya and nawädir synonymously. He extended the meaning and scope of nawädir, a concept that had been put mostly under the heading of ghayr zähir al-riwāya. Thereby, certain books, such as al-Raqqiyyāt, al-Kaysāniyyāt, al-Jurjāniyyāt, and al-Hārūniyyāt, which had been known as works of ghayr zähir al-riwāya, came to be known as works of nawädir and were attributed to Shaybānī. However, even though al-Raqqiyyāt and al-Kaysāniyyāt belonged to Shaybānī, they were ultimately amālī works. In addition, while al-Jurjāniyyāt was another amālì work transmitted by Ali b. Șāliḥ from Abū Yūsuf, al-Hārūniyyāt belonged to Ḥasan b. Ziyād. Classifying the Hanafi responsa under three categories in Tabaqāt al-masā'il, Kınalızade assigns wider meanings to the concepts $u s \underline{u} l$ and nawädir than in earlier periods. Kinalizade extended the meanings of the concepts of zähir al-riwāya and ghayr zāhir al-riwāya, which Shaybānī used for identifying books, by adding legal questions and books belonging to Abū Hanifa's other students. He even formed a classification comprising all issues of the school by adding the responsa of other jurists under the heading of fatāwa . His definitions and classifications have reached us through later scholars who carried them on.

The treatise includes some information that does not conform to the early period in its presentation of new definitions of basic concepts under triple classification and for its examples of works. However, it remains significant as the first, and a uniquely independent, treatise on the categorization of the legal responsa in the Hanafi school and for its impact on the ensuing literature.

Keywords: Hanafi school of law, țabaqāt al-masā’il, zāhir al-riwāya, ghayr zִāhir alriwāya, al-ușūl, al-nawādir, al-fatāwā. 
